\title{
GIFTS OVER ON DEATH WITHOUT ISSUE
}

\author{
JOSEPH WARREN
}

\section{HISTORICAL INTRODUCTION}

Prior to the Statute of Uses, ${ }^{1}$ if a gift of Blackacre was made "to $A$ and his heirs, but if $A$ died without heirs of his body (or issue), to $B$ and his heirs," the gift to $B$ and his heirs, taking effect by way of shifting use and not by way of remainder, was void. ${ }^{2}$ It was natural, therefore, for a court which wished to save the gift to $B$ to construe it as a remainder. This could best be done by implying an estate tail in $A$, with a gift over upon its expiration to $B .^{3}$ After the passage of the Statute of Uses and the Statute of Wills, shifting and springing gifts, which of course took effect other than by way of remainder, were held valid. ${ }^{5}$ At this time, if there was a feoffment or a devise of Blackacre "to $A$ and his heirs, but if $A$ died without issue, to $B$ and his heirs," it was not necessary to interpret $B$ 's gift as a remainder in order to save it. Yet it was so construed, the old law prevailing. If a chattel real were so limited, its gift over to $B$ was held void as an attempt to entail a term. ${ }^{\circ}$ No case of such a limitation of chattels personal has been found at this period.

In 1620, Pells $v$. Brown ${ }^{7}$ held executory devises to be indestructible. This decision necessitated the Rule against Perpetuities, initiated by Lord Nottingham in $1682 .{ }^{8}$ Thereafter, if

127 HEN. VIII, c. 10 (1535).

2 KALES, Estates AND FUTURE INTEREsts (2d ed. 1920) § 26.

${ }^{3}$ An early instance of such an interpretation took place in the 85 th year of Edward III (1361). There was a gift of land to $B$, to him and his heirs, to have and to hold, to $B$ and his heirs forever, if $B$ had issue of his body, and if he died without heir of his body, the land was to revert to the donor and his heirs. $B$ had issue, and that issue died without heir of his body. The suit was between the collateral heirs of $B$ and the donor. It was adjudged that $B$ had only a fee tail and that, because $B$ had died without heir of his body, the donor recover. Lib. Assis. $35 \mathrm{Edw}$. III pl. 14 (1361) ; BRooke's Abridgment, Estate (15T6) 36, Taile 20; FitzinerBERT'S ABRIDGMENT (1577) Taile 17. Such was the English law down to the Wills Act of 1838. THEOBALD ON WILLS (8th ed. 1927) 208.

432 \& 34 HEN. VIII, c. 1 (1540).

5 Gray, Rule against Perpetuities (3d ed. 1915) § 135.

6 See Child v. Baylie, 3 Cro. Jac. 459,460 (1618); GraY, op. cit. supra note 5 , §§ 155-158.

7 Cro. Jac. 590 (1620).

${ }^{8}$ Duke of Norfolk's Case, 3 Cas. Ch. 1 (1682); GRAY, op. cit. supra noto 5, $\$$ 169-170. 
there was a devise of Blackacre "to $A$ and his heirs, but if $A$ died without heirs of his body (or issue), to $B$ and his heirs," in order to save $B$ 's gift under the new rule against the creation of remote interests, it was necessary either to construe $B$ 's gift as taking effect at some definite near period, such as if $A$ died without heirs of his body (or issue) surviving $A$, or to give $B$ by interpretation a remainder after an estate tail. ${ }^{\circ}$ To the medieval judge the choice was clear, and the old method persisted. This meant, of course, that $A$ 's death without heirs of his body (or issue) signified a period whenever $A$ 's line ran out, no matter when. After future interests in chattels real and personal vere permitted in the 17th and 18th centuries, difficulties at once arose as to the remoteness of the gift to $B$ and his executors when the devise of chattels personal or real ran "to $A$ and his executors, and if $A$ died without issue, to $B$ and his executora."

Another related circumstance naturally led to the legal view that $A^{\prime}$ 's death without heirs of his body or without issue meant when $A$ 's line ran out, no matter when, and not when it was extinct at $A^{\prime}$ 's death or at some other definite future time. For centuries it has been the custom of solicitors in England in the setilement of large landed estates to limit one or more estates tail with remainders thereafter, ${ }^{10}$ The common form of such an estate tail was " $A$ and the heirs of his body," and the customary way to introduce the remainder after such an estate was to adopt a form similar to one of the followine:

If $A$-die without heirs of his body.

For want of such heirs of $A$ 's body.

In default of such issue of $A$. '

In default of issue of $A .{ }^{12}$

While the word "such" generally appears, some of the forms do not employed the word.12 Indeed, in the form given in Key and Elphinstone's Conveyancing, ${ }^{13}$ both "in default of such issue," and "if there should be a failure of issue" are used." It seems, therefore, that it was a matter of indifference whether or not the

- See cupra note 3.

10 The best description of English family settlements is to be found in Wininams, Setriements of Reni Estate (1879) c. 15. It is not within the scope of this paper to describe them in detail.

11 The forms appear in Madox, Forurulare ANGucanurs (1702) 93, 398415, especially forms Nos. 170, 725-728, 745-749, which cover Eettlements in the reigns of Edward I, II, III, Richard II, Henry IV, V, VI, VII, and VIII. Also in Brmgaran, CoNveYANCes (1st ed.) 7, 63, 332; 7 BYzHETOOD, PRECEDENTS (1834) 363; 2 KEY AND ElphINSTONE, Conveyancing (8th ed. 1904) 599; White v. Summers, [1908] 2 Ch. 256, 271-72.

12 MadoX, op. cit. supra note 11, forms Nos.725, 728.

${ }^{13}$ Loc. cit. supra note 11.

14 See also White v. Summers, supra note 11, at 272. 
referential word "such" was employed. Of course $A$ 's estate tail would run out and the next interest take effect if $A$ 's line at any time was exhausted. Thus, the remainder would become an estate in possession when $A$ died without descendants him surviving, or if $A$ 's line ran out at any time after $A$ 's death, as when $A$ 's great, great grandson died a bachelor.

Nothing could be more natural, therefore, to the English lawyer of the last 600 years than to attribute to the words "die without heirs of the body," or "die without issue," a meaning totally at variance with the layman's idea of the expression.

Normally, when the testator gives an interest to a person and his heirs, with a gift over if that person dies without issue, the testator means that the devisee shall lose the estate only if on his death he leaves no heirs of his body him surviving. But to the mediæval, and even to the modern, lawyer, a man died "without issue" whenever his line ran out. This was the legal interpretation prior to the Wills' Act of 1838. As is stated in Jarman on Wills:

"Words referring to the death of a person without issue, whether the terms be, 'if he die without issue, "if he have no issue,' or 'if he die before he has any issue,' or 'for want' or 'in default of issue,' unexplained by the context, and whether applied to real or to personal estate, (notwithstanding the distinction taken between these two species of property in some of the early cases) are construed to import a general indefinite failure of issue, i.e., a failure or extinction of issue at any period." 15

In almost every case calling for a differentiation of construction of this expression "dying without issue" the court was presented with the alternative of construing it as a failure of issue at any time (an indefinite failure of issue), or a failure of issue at the death of the first taker (definite failure of issue). Theoretically definite "failure of issue" means a failure at some specified time. By far the most common point of time found in practice is the death of the first taker. As Jarman expresses it, however, the event specified might be "collateral to the devisee," as in a devise to $A$ and his heirs with a devise over in case he should die without issue in the lifetime of $B$. Suppose during the lifetime of $B, A$ dies leaving a child who in turn dies before $B$; has the event happened upon which the gift is to go over? Crowder $v$. Stone ${ }^{16}$ seems to be the only case involving this question. Lord Lyndhurst held that the gift over took effect.17 A possible construction even here might be, that, inasmuch as the testator could not have meant a failure of issue at any time,

15 JARMAN ON WiLls (1st ed. 1844) 418.

163 Russ. 217 (1827).

17 But cf. Nichols v. Hooper, 1 P. W. 198 (1790). 
he must have meant that other failure of issue which is more commonly referred to in wills, i.e., failure of issue at the death of the first taker.

As has been pointed out, if there was a devise of land to $A$ and his heirs, followed by a gift over if $A$ died without heirs of his body (or without issue), $A$ 's estate was cut down to an estate tail and the gift over became a remainder immediately following. ${ }^{18}$ And, likewise, if there was a devise to $A$ for life, followed by a gift over on default of $A$ 's issue, $A$ took an estate tail by construction. $^{19}$ As an estate tail in possession could be barred, turned into a fee simple absolute, and all interests thereafter destroyed at the will of the owner, $A$ was able at once to acquire the whole fee simple entirely contrary to the intent of the testator. $^{20}$ On the other hand, if the subject matter of the gift was personalty, in which there could be no estate tail, the gift over, arising, as it was said, on a general failure of issue, was void for remoteness. ${ }^{21}$ It resulted from this difference between the two classes of property that the judges were more prone in personalty than in realty to find on the face of the instrument a special context limiting the gift over upon failure of issue to the death of the first taker. And this remained true, in spite of the well known principle that the rule against perpetuities should not be employed for the purpose of construction.

It is necessary to consider what expressions have been commonly construed sufficient in England to cut down the generality of the meaning of "dying without issue" from an indefinite to $a$ definite failure thereof.

(1) Where the failure of issue is stated to take place during the life of some living person. Thus, where there was a devise "to $A$ and his heirs, but if $A$ died without issue living $B$ over," it was held that $A$ did not take an estate tail.s2 $A$ fortiori, if the subject matter of the gift be personalty, a definite fa'lure of issue would result. ${ }^{23}$ It would seem that the same reasoning would apply where the gift over is to a person alive at the time of the testator's death and designed to be living at the time that he is to take. Thus, if the gift over is to survivors of persons alive at the testator's death, the event upon which it is conditioned should be held to be upon a definite failure of issue. This result is reached if the subject matter of the bequest is personalty. ${ }^{24}$ But, if the will be one of land, Chadock v. Cowley 25

\footnotetext{
18 The0BAL, op. cit. supra note 3 , at 819.

$19 \mathrm{Ibid}$.

20 Williams, Real Property (23d ed. 1920) 272.

212 Jarian, op. cit. supra note 15, at 427.

22 Pells v. Brown, supra note 7, at 695 .

${ }^{23}$ Cf. Crowder v. Stone, supra note 16.

24 Hughes v. Sayer, 1 P. Wms. 534 (1790).

253 Cro. Jac. 695 (1625).
} 
decided without sufficient reason that the common law construc- tion prevails. On the other hand, if the gift over is to some one for life and there is no further devise of the property, Rowe $v$. Jeffrey ${ }^{26}$ has held in the case of land that a definite failure of issue is meant.

(2) If the expression used is "dying without leaving issue," a definite failure of issue is intended in a bequest of personalty, but an indefinite failure of issue in a devise of realty. It was so held in Forth $v$. Chapman. ${ }^{27}$ Very little, however, is necessary to bring the devise of land into line with the bequest of chattels in this respect. Thus, the expression "leaving no issue behind him" was sufficient to accomplish this purpose. ${ }^{28}$

(3) Finally, it would seem, both as to realty and personalty, if the expression "after his death," or the like, be coupled with "dying without issue," a definite failure of issue is intended."

Unless there is some special language appearing on the face of the instrument creating it, such, for instance, as an estate tail in the first taker, a gift over on $A$ 's death without issue should be interpreted as a gift over on $A$ 's death without issue him surviving. This result was finally reached in England by the enactment of the Wills Act of $1838,{ }^{30}$ which provides:

"... that in any devise or bequest of real or personal estate, the words 'die without issue,' or 'die without leaving issue,' or 'have no issue,' or any other words which may import either a want or failure of issue of any person in his lifetime or at the time of his death, or an indefinite failure of his issue, shall be construed to mean a want or failure of issue in the lifetime or at the time of the death of such person, and not an indefinite failure of his issue, unless a contrary intention shall appear by the will, by reason of such person having a prior estate tail, or of a preceding gift, being (without any implication arising from such words) a limitation of an estate tail to such person or issue; or otherwise; provided, that this act shall not extend to cases where such words as aforesaid import if no issue described in a preceding gift shall be born, or if there shall be no issue who shall live to attain the age, or otherwise answer the description required for obtaining a vested estate by a preceding gift to such issue."

\section{AMERICAN STATUTES}

In the 17th and early 18 th centuries, estates tail were favored in Virginia. Indeed, in 1710 estates tail were protected from

${ }^{26} 7$ T. R. 589 (1798).

271 P. Wms. 663 (1790).

28 Porter v. Bradley, 3 T. R. 143 (1789).

${ }^{20}$ Trotter v. Oswald, 1 Cox 317 (1787); Ex parte Davies, 2 Sim. (N. S.)

114 (1854).

301 VICT. c. $26, \S 29$ (1837). 
destruction by fine and recovery. In 1727 slaves were subjected to the limitations in tail by being anniexed to lands in tail to pass with the land itseif. 'In 1734 there might be the docking of a fee tail under certain conditions. However, at the first session after the Declaration of Independence, the legislature declared that tenants in tail of land or of slaves should hold them in fee simple. $^{31}$

Since that time many American jurisdictions have abolished by statute estates tail. 'In twenty-three jurisdictions the statute enacts that a limitation formerly sufficient to create an estate tail now creates either a fee simple absolute, or a fee simple with an executory limitation taking effect only if the first taker dies. without issue him surviving. "In eight states an estate tail now becomes a life estate in the first taker with a remainder in fee simple ahsolute in the next taker. In three states it becomes an iestate tail for the life of the first taker only, and then a fee simple absolute in those who take by inheritance from him. In only six states are we certain that estates tail exist today.92

Virginia took the lead; not only of all the American states but of England, in abolishing by statute the prima facie meaning to the common law of England of "dying without issue." In 1819 it passed a statute which reversed the common law presumption, and àdopted the prima facie presumption that failure of issue at the death of the person is meant, unless "the intention of such limitation be otherwisé expressly and plainly de-

$\therefore 2$ Beackstone, Colmentaries (Tugkerig 1st Am. Ed. 1803) 116, n. 119; see 4 DANE'S ABRmgMENT (1824) 621.

Thomas Jefferson was responsible for this enactment. On Oct. 12, 1776, "He obtained leave to bring in a bill to enable tennnts in tail to convey entailed property in fee simple. Two days later he reported a bill doing away with the whole system of entail. It was an audacious move. From generation to generation lands and slaves-almost the only valuable bind of property in Virginia-had'been handed down protected against creditors, even against the very extravagance of, spendthrift owners; and it was largely by this means that the quasi-nobility of the colony had succeeded in establishing and maintaining itself. A great groan seemed to go up from all respectable society at the terrible suggestion of Jefierson, a suggestion daringly cast before an Assembly thickly sprinlsled with influential delegates strongly bound by family ties and self-interest to defend tho present system. Recards of the times fail to explain the sudden and surprising success of a reform, Which there was every reason to suppose could be carried through only very. slowly and by desperate contests; we know little more than the strange fact that the whole system of entail in Virginia crashed to pieces almost literally in a day, carrying with it an aristocracy somewhat brummagen, but the only one which has ever existed in the territory now of the United States." MIORSE, Thousas JefrersoN (1883) 43; see 1 Fiske, OLD VIRGINLA (1901) 40.

32 The jurisdictions are classified down to January 1,1928 , in $\mathrm{LAT}$ of Propgety Restatement (Am. L. Inst 1928) Draft 16, pp. 7-11. 
clared on the face of the deed or will creating it." as The modern West Virginia statute has, of course, its origin in the same act, and it has also been followed more or less literally in Mississippi, ${ }^{34}$ North Carolina, ${ }^{35}$ New Jersey, ${ }^{36}$ Tennessee, ${ }^{37}$ Kentucky, ${ }^{38}$ District of Columbia, ${ }^{39}$ Maryland, ${ }^{40}$ Massachusetts, ${ }^{42}$ Rhode Island, ${ }^{42}$ and Pennsylvania. ${ }^{43}$

In accordance with the English common law, New York early held that "dying without issue" meant an "indefinite failure of issue. ${ }^{44}$ This had been assumed in earlier cases, which held, however, that a definite failure of issue was meant, because of the gift over to a certain person as "survivor." 45 Chancellor Kent seemed perfectly clear in his own mind that the common law rule was the law of New York. Indeed, he thought that the common law rule was based upon the intent of most testators. ${ }^{46}$ In 1782 New York had abolished fees tail by turning them into fees simple. ${ }^{47}$ The Revised Statutes of 1830 contained the following provisions:

"Where a remainder in fee shall be limited upon any estate,

${ }_{33}$ VA. Rev. CoDe (1819) c. 99, \& 26: "Every contingent limitation in any such deed or will made to depend upon the dying of any person without heirs or heirs of the body or without issue, or issue of the body, or without children, or off spring, or descendant, or other relative, shall be held and interpreted a limitation to take effect when such person shall die, not having such heir or issue, or child, or offspring, or descendant, or other relative, as the case may be, living at the time of his death, or born to him within ten months thereafter, unless the intention of such limitation bo otherwise expressly and plainly declared on the face of the deed or will creating it."

34 Hutchinson, Digest (1822) 610.

${ }^{35}$ N. C. Acts $1827-28$, c. 7.

${ }^{36}$ N. J. Acts 1851, p. 218.

3\% Tenn. Laws $1851-52$, c. 41, p. $113, \S 3$.

$38 \mathrm{Ky}$. Rev. Stat. (1852) c. $80, \S 9$.

39 D. C. Rev. CoDe (1857) tit. 1 , c. $48, \S 45$.

40 Md. Laws 1862 , c. 161 ; Md. Laws 1866, c. 236.

41 Mass. Acts 1888 , c. 273.

42 R. I. GEN. LAwS (1896) c. 202 , § 24.

$43 \mathrm{~Pa}$. Act. July 9, 1897, P. L. 213 (1897) Act 172.

14 Jackson v. Bellinger, 18 Johns. 368 (N. Y. 1820) ; Lion v. Burtiss, 20

Johns. 483 (N. Y. 1823); Wilkes v. Lyon, 2 Cow. 333 (N. Y. 1823).

4) Fosdick v. Cornell, 1 Johns. 440 (N. Y. 1806); Jackson v. Blanshan, 3 Johns. 289 (N. Y. 1808) ; Moffat v. Strong, 10 Johns. 12 (N. Y. 1813); Anderson v. Jackson, 16 Johns. 382 (N. Y. 1819).

46 "I am inclined to think that in 19 cases out of 20 the testator really means a general or indefinite failure of issue." Anderson v. Jackson, oupra note 45 , at 401 . He repeated the same opinion in 4 KENT, Commentanies *274. In Anderson v. Jackson, Kent had dissented and had reversed his concurrence in the opinion of Fosdick v. Cornell, supra note 45, which held that the word "survivor" had the effect of restricting the common law meaining of "dying without issue."

${ }^{47}$ N. Y. Laws, '́less. 6, c. 2; Sess. 9, c. 12. 
which would be adjudged a fee tail, according to the law of this state, as it existed previous to the time mentioned in the last section, such remainder shall be valid as a contingent limitation upon a fee, and shall vest in possession, on the death of the first taker, without issue living at the time of such death." 43

\section{And Section 22 read:}

"Where a remainder shall be limited to take effect on the death of any person without heirs, or heirs of his body, or without issue, the words 'heirs' or 'issue' shall be construed to mean heirs or issue, living at the death of the person named as ancestor." 10

The revisers in their report to the legislature commented acutely on the expression "dying without issue." They noted the common law meaning of it and Chancellor Kent's approval thereof, and said:

"In most cases, it is expressed that the limitation over shall take effect on the event of the first taker's 'dying with out issue, or without leaving issue'; and in these cases, it is believed that the meaning which the law affixes to the terms, namely, a failure of issue, at any period however remote, even after the death of the first taker, is very opposite to that of the party by whom they are employed." so

Referring to the New York cases in Johnson's reports cited above, they said:

"The tendency of the sect:ons that we have proposed to prevent litigation may be fairly stated, as an additional argument in favor of their adoption. Nearly every case that has arisen in our own courts in relation to executory devises and other contingent limitations has turned on the question, whether the first taker took an estate tail, or in other words, whether the remainder were dependent on an indefinite failure of issue. (1 Johns. $R$. $440 ; 10$ Johns. R. 12,$19 ; 11$ Johns. R. $337 ; 16$ Johns. R. $382 ; 18$ Johns. R. $368 ; 20$ Johns. R. 483). In all of these cases, the struggle of the judges to support the limitation over, by confining the failure of issue to the death of the first taker, is very manifest."

Section 22 of the New York Revised Laws of 1830 has been substantially copied in Missouri, 51 Michigan, ${ }^{52}$ Wisconsin,,33 Minnesota, ${ }^{55}$ New Mexico, ${ }^{55}$ Alabama, ${ }^{56}$ South Carolina, ${ }^{57}$ Georgia,,33

\footnotetext{
48 N. Y. Rev. StaT. (1830) pt. 2, tit. 2, $\$ 4$.

40 Ibid. § 22 .

s0 3 ANALYsis of Revised Statutes (1828) pt. 2, c. 1, tit. 2, art. 1, p. 12.

s1 Mo. Acts 1845, c. $32, \S 6$.

52 MIICH. REV. STAT. (1846) pt. 1, tit. 14, c. 62, § 22.

53 Wis. Rev. Stat. (1849) pt. 2, tit. 15, c. 56, $\$ 22$.

54 MINN. Rev. Stat. (1851) c. $43, \S 22$.

55 N. M. Laws 1851-52, pp. 377, 381, § 25.

56 AJA. CODE (1852) § 1302.

57 S, C. Stat. AT Large (1853) 298.

$58 \mathrm{Ga}$. Laws 1853-54, p. 72, No. 62.
} 
California, ${ }^{50}$ Nevada, ${ }^{60}$ Idaho, ${ }^{62}$ Montana, ${ }^{62}$ North and South Dakota, ${ }^{63}$ and Arizona. ${ }^{64}$

Between the Virginia Act and the New York Act there is this difference in form: the Virginia statute provides that the presumption of definite failure of issue can be rebutted by a contrary intent appearing in the will, while the New York statute contains no such provision and says, apparently peremptorily, that the words "shall be construed" to mean heirs or issue living at the death of the person named as ancestor. Does this strict language used in the New York Act preclude the possibility of rebutting the new meaning? Chancellor Kent has some language in his Commentaries suggesting that the rule in New York is a hard and fast one and unrebuttable. ${ }^{65}$ But no case has been found in New York, or in any other jurisdiction, which raiges this question. It is extremely. unlikely that any such case should occur in a country hostile to estates tail and where the rule againgt perpetuities prevents remote limitations on indefinite failure of issue. Nor has any analogy been found with respect to any other statute laying down in absolute terms a rule of construction for wills. It is submitted that just as the common law rule was rebuttable by appropriate language on the face of the will, ${ }^{\circ 0} 80$ the New York statutory rule was not intended to be any more stringent in its application. If any testator were rash enough in other parts of his will to say that he meant the expresaion "dying without issue" to have the old common law meaning, it in believed that the New York courts would consider the statutory rule inapplicable.

The writer believes that the form embodied in the Wills Act in England and the Virginia act in the United States is the better, and suzgests the form prepared by Professor Ernest Freund, ${ }^{67}$ with the addition of the proviso contained in both statutes just referred to, so as to read as followa:

"In any gift, grant, or devise hereinafter taking effect, a limitation of an executory interest contingent upon the event of 8 prior taker 'having no issue' or 'dying without issue' or 'dying without leaving issue' (or using words of similar import), shall not be held to refer to an indefinite failure of issue, but shall be deemed to refer to the want or failure of issue at the time of

\footnotetext{
50 Cal. Acts April 27, 1855, p. 171.

${ }^{60}$ Nev. Terr. Laws 1861, c. 9, $\S 43$, p. 17.

${ }^{61}$ Idaho Laws 1863-64, p. 535, \& 44 .

62 Mont. Terr. Laws 1864, p. 479.

${ }^{63}$ Dak. Crvil Code (1864-65) art. 4, \& 477.

64 ARIZ. Rev. STAT. (Civil Code 1913) § 4687 .

${ }^{65} 4 \mathrm{KENT}$, op. cit. supra note 46 , at *281, note a.

66 See supra note 45.

o7 This appears in Kause, Cases on Furure INTERests (1917) 535.
} 
the death of the person named as ancestor, unless a contrary intention shall appear from the instrument creating it."

A classification of the statutes appears in a note. ${ }^{08}$

\section{AMERICAN LAW APART FROM STATUTE}

In a country so hostile to entails, it is surprising that the expression "dying without issue" should be employed in wills to the extent that our litigation shows. The reckless use of the phrase is probably due to custom and to the fascination which the elusive word "issue" has had for the layman and for the lawyer little versed in conveyancing.

68 (1) States in which the statute applies to all situations:

$\begin{array}{ll}\text { Alabama } & \text { New York (see } 5 \text { infra) } \\ \text { District of Columbia } & \text { North Carolina } \\ \text { Georgia } & \text { Rhode Island } \\ \text { Maryland } & \text { South Carolina } \\ \text { Massachusetts } & \text { Tennessee } \\ \text { Mississippi } & \text { Virginia }\end{array}$

(2) States in which the statute applies to wills only:

New Jersey Pennsylvania

(3) States in which the statute applies to deeds only:

$\begin{array}{ll}\text { California } & \text { New Mexico (?) } \\ \text { Idaho (?) } & \text { North Dakota (?) } \\ \text { Montana (?) } & \text { South Dakota (?) }\end{array}$

Tevada (?

(4) States where the statute applies to real property only:

$\begin{array}{ll}\text { Axizona } & \text { North Daliota } \\ \text { Kentucky } & \text { South Dakota } \\ \text { Michigan } & \text { West Virginia (?) } \\ \text { Minnesota } & \text { Wisconsin }\end{array}$

(5) States where the statute in terms applies only to remainders:

$\begin{array}{ll}\text { Alabama } & \text { Nissouri } \\ \text { Arizona } & \text { Nontana } \\ \text { California } & \text { Nevada } \\ \text { Idaho } & \text { New York } \\ \text { Michigan } & \text { Wisconsin }\end{array}$

In these states (No. 5) the New York definition of "remainder" would probably be applied so as to give the statute a broad application to all future interests. The, New York statute is as follows: "Where a future estate is dependent on a precedent estate, it may be termed a 'remainder,' and may be created and transferred by that name." N. Y. REV. STAT. (1830) pt. 2, tit. 2, art. 1, §11.

In compiling the above table there has been used a degrce of dogmatism which may not be justified by the future development of these statutes by the courts. Where the act is apparently limited with respect to land or personalty or to a certain type of conveyance, the judges may strain to extend its application by interpretation. And if that is impossible, the step taken by the legislature may encourage the courts to repeal the common law to which the act has failed to extend. This is a familiar process. See (1921) 31 HARV. L. REv. 526. 
It is perhaps more astonishing that the phrase should have here received so widely its absurd common law interpretation. Many of such decisions, however, were made before the middle of the nineteenth century. Furthermore, a goodly proportion of those handed down thereafter involved wills of much earlier date. Something is also due to the early. legal education of our judges who, like Chancellor Kent, ${ }^{40}$ were brought up under the influence of the eighteenth century English decisions and who felt unable to break away from them even under a different state of society.

A great majority of our judgres have required legislation, or some context upon the face of the will, to hold the gift over to be on a definite failure of issue. Kentucky, Connecticut and Ohio alone have been bold enough to accomplish this without either of these aids." The Kentucky and Connecticut decisions would seem to include both land and personalty, but the subject matter of the dispute in the Ohio case was land." But the great weight of American anthority, both as to land **

$\because 4$ KFNT, op. cit, supra note 46 , at $\$ 274$.

i" Northcut v. Whipp, 12 B. Mon. 65 (Ky. 1851); Moore v. Moore, 12 B. Mon. 651 (Ky. 1851); Hudson v. Wadsworth, 8 Conn. 347 (1831); St. John v. Dann, 66 Conn. 401, 407 (1895) (land and personalty); Parish v. Ferris, 6 Ohio St. 563 (1856); Niles v. Gray, 12 Ohio St. 320 (1801), approved in Anderson v. Realty Co., 79 Ohio St. 23 (1908); cf. Harris v. Smith, 16 Ga. 545 (1855) semble; Summers v. Smith, 127 Ill. 645 (1889) scmblc; McAllister v. Elliott, 14 Atl. 208, 711 (N. H. 1928) semble.

"Parish v. Ferris, supra note 70.

The hostility in Kentucky to English precedents has been noted in GaAY, The Nature and Sources of the Law (2d ed. 1921) $245 \mathrm{n}$. 1 . Sce CueavelaNd, Hewitt ajd Clark, Probate law and Practice in Connecticut (1915) 921 .

${ }^{72}$ An indefinite failure of issue was held. to be meant in the following cases involving land:

Arkansas: Mercantile Trust Co. v. Adams, 95 Ark. 333, 129 S. W. 1101 (1910).

Georgia: Wiley, Parish \& Co. v. Smith, 3 Ga. 551 (1847); Hertz v. Abrahams, 110 Ga. 707,36 S. E. $409(1000)$.

Indiuna: Huxford v. Milligan, 50 Ind. 542 (1875).

Kansas: Klingman v. Gilbert, 90 Kan. 545, 135 Pac. 682 (1913) semble.

Maine: Fisk v. Keene, 35 Me. 349 (1853); Richardson v. Richardson, 80 Me. 585 (1888); Skolfield v. Litchfield, 116 Me. 140, 102 Atl. 240 (1917). Maryland: Laidler v. Young, 2 H. \& J. 69 (1807); Newton v. Grimth, 1 H. \& G. 111 (1827); Pennington v. Pennington, 70 Md. 418 (1889); Comegys v. Jones, 65 Md. 317 (1886).

Massachusetts; Hawley $v$. Northampton, 8 Mass. 3 (1811); Hurlburt v. Emerson, 16 Mass. 241 (1819); Parkman v. Bowdoin, 1 Sumn. 319 (C. C. D. Mass. 1833); Nightingale $v$. Burrell, 15 Pick. 104 (18:33); Parker $v$. Parker, 5 Mete. 134 (1842); Malcolm v. Malcolm, 3 Cush. 172 (1840); Wheatland v. Dodge, 10 Metc. 502 (1345); Terry v. Briggs, 12 Mete, 17 (1845); Hall v. Priest, 6 Gray 18 (1856); Brown v. Addison Hospital, 155 Mass. 323,29 N. E. 625 (1892); Allen v. Trustees, 102 Mass. 262 
and personalty, 73 is in favor of the common law pre-

(1869) ; Hayward v. Howe, 12 Gray 49 (1858); Gilkie v. Marsh, 186 Mass. 336, 71 N. E. 703 (1904).

New Hampshire: Hall v. Chafee, 14 N. H. 215 (1843) semble; Mlerrill v. Baptist Union, 73 N. H. 414 (1905).

New Jersey: Secquil v. Moore, 1 Coxe 386 (N. J. L. 1795); Mlorehouse ч. Cotheal, 2 Zab. 430 (1850) (reversed on collateral point); Chetwood $\because$. Winston, 40 N. J. L. 337 (1878) ; More v. Rake, 2 Dutc. 574 (1857) semble.

New York: Wilkes v. Lion, 2 Cow. 333 (1823).

North Carolina: Moore

Pennsylvania: Haines r. Witmer, 2 Yeates 400 (1798); Hope v. Rusha, $88 \mathrm{~Pa} .127$ (1878); Caskey v. Brewer, 17 S. \& R. 441 (1828); Clark v. Baker, 3 S. \& R. 470 (1817) semble; Burkart v. Bucher, 2 Binn. 455 (1810); Wall . MicGuire, 22 Pa. 248 (1855); Doyle v. Miullady, $33 \mathrm{~Pa} .264$ (1859); Rancel v. Creswell, $30 \mathrm{~Pa} .158$ (1858) semble; Sharp v. Thompson, 1 Whart. 139 (1836); Braden v. Cannon, 24 Pa. 168 (1854); Reinoehl v. Shirk, 119 Pa 108 (1888); Duer v. Boyd, 1 S. \& R. 202 (1814); 3ioody v. Snell, 81 $\mathrm{Pa} 359$ (1876); Pierce v. Hakes, $23 \mathrm{~Pa} .231$ (1854); Wynn v. Story, $38 \mathrm{~Pa}$. 166 (1861) ; Criley v. Chamberlain, 30 Pa. 161 (1858); Covert v. Robinson, $46 \mathrm{~Pa}$. 274 (1863); Ray v. Alexander, $146 \mathrm{~Pa} .242$ (1891); Robinson's Estate, 149 Pa. 418 (1892); Eichelberger v. Barnitz, 9 Watts 447 (1840); Lawrence v. Lawrence, $105 \mathrm{~Pa} .335$ (1884); Vaughan v. Dickes, $20 \mathrm{~Pa} .509$ (1853); Arnold v. Muhlenberg College, 227 Pa. 321, 76 Atl. 30 (1910); Beilstein v. Beilstein, $194 \mathrm{~Pa}$. 152, 45 Atl. 73 (1899); Grabam v. Abbott, 208 Pa. 68, 57 Atl. 178 (1904); Amelong v. Dorneyer, 16 S. \& R. 322 (1827); Irwin v. Dunwoody, 17 S. \& R. 60 (1827); Hansell v. Hubbell, 24 Pa. 244 (1855); Horton v. MicCall, $233 \mathrm{~Pa} .405,82$ Atl. 472 (1912); Hackney v. Tracy, $137 \mathrm{~Pa} .53$ (1890); Heffner v. Knepper, 6 Watts 18 (1837).

Rhode Island: Whitford v. Armstrong, 9 R. I. 394 (1870); Holden v. Wells, 18 R. T. 802 (1895); Osborne v. Shrieve, 3 Mas. 391 (C. C. D. R. I. 1824).

South Carolina: Clifton v. Haig, 4 Des. Eq. 330 (1812) semble; Mrazycls v. Vanderhorst, 1 Bailey Eq. 48 (1828); Graham v. Moore, 13 S. C. 115 (1879) semble; Mangum v. Piester, 16 S. C. 316 (1881).

Tennessee: Hamner v. Hamner, 3 Head 398 (1859); Chester v. Greer, 5 Humph. 26 (1844).

Virginia: Callava v. Pope, 3 Leigh. 103 (1831); Bells v. Gillespie, 5 Rand 273 (1827); Broaddus v. Turner, 5 Rand 308 (1827); Wright v. Cohoon, 12 Leigh. 370 (1841); Hill v. Burrow, 3 Call 297 (1803); Tate จ. Tally, 3 Call 307 (1803); Carter v. Tyler, 1 Call 165 (1797); Jiggetts v. Davis, 1 Leigh. 368 (1829) ; Tinsley v. Jones, 13 Gratt. 289 (1856); See v. Craigen, 8 Leigh. 449 (1836); Roy v. Garnett, 2 Wash. 11 (Va. 1794).

${ }^{73}$ An indefinite failure of issue was held to be meant in the following cases involving personalty:

Moody v. Walker, 3 Ark. 147 (1840) semble; Watkins v. Quarles, 23 Ark. 179 (1861); Gray v. Gray, 20 Ga. 804 (1856); Huxford v. Milligan, 50 Ind. 542 (1875); Allender v. Sussan, 33 Md. 11 (1870) remble; Albee v. Carpenter, 12 Cush. 382 (Mass. 1853); Hall v. Priest, f Gray 18 (Mass. 1856) semble; Vaughn v. Guy, 17 Mo. 429 (1853); Chism's Adm'r v. Williams, 29 Mo. 288 (1860); Davies v. Stcele, 38 N. J. Eq. 168 (1881); Patercon v. Ellis, 11 Wend. 259 (N. Y. 1833) smble; Moftat v. Strong, 10 Johns. 12,16 (N. Y. 1813) semble; Norris v. Beyea, 13 N. Y. 273, 280 (1855); Hoff's Estate, 147 Pa. 636 (1892); Clifton v. Haig, supra note 72 (S. C.) ; Postell v. Postell, 1 Bailey Fq. 330 (S. C. 1831); Randolph v. 
sumption. ${ }^{74}$

The expressions upon the face of the will which have been urged to cut down the common law meaning are the same as those noted above in connection with the English law.

(1) If the gift over is to a person designated as "then living" or "surviving," the weight of authority in the case of land, contrary to Chadock v. Cowley, ${ }^{75}$ is in favor of holding that the popular meaning is meant. ${ }^{76}$ There is a substantial minority of

Wendel, 4 Sneed 646 (Tenn. 1857); Bowman v. Tucker, 3 Humph. 648 (Tenn. 1842); Chester v. Greer, supra note 72 (Tenn.); Nixon v. Rose, 12 Gratt. 425 (Va. 1855); Deane v. Hansford, 9 Leigh. 253 (Va. 1838); Williamson v. Ledbetter, 2 Munf. 521 (Va. 1811); Callava v. Pope, 3 Leigh. 103 (Va. 1831).

71 The minority view is represented by the following cases:

Land: Clarke v. Turry, 34 Conn. 176 (1867); Harris v. Smith, 16 Ga. 545 (1855); Summers v. Smith, 127 Ill. 645 (1889) semble; Moore v. Moore, 12 B. Mon. 651 (Ky. 1851) ; Northcut v. Whipp, 12 B. Mon. 65 (Ky. 1851); Black v. Cartmell, 10 B. Mon. 188 (Ky. 1849) semble; McAllister v. Elliot, 140 Atl. 708,711 (N. H. 1928) semble; Parrish v. Ferris, 6 Ohio St. 56.3 (1856).

Personalty: Clarke v. Turry, supra; Harris v. Smith, 16 Ga. 545 (1855) semble; Moore v. Moore; Black v. Cartmell, both supra.

75 Supra note 25.

76 "Survivor"-Land-Definite Failure Intended: Jackson d. St. John v. Chew, 12 Wheat. 153 (U. S. 1827); Morgan v. Morgan, 5 Day 517 (Conn. 1813) semble; Couch v. Gorham, 1 Conn. 36 (1814); Blanchard v. Maynard, 103 IIl. 60 (1882) semble; Carpenter v. Sangamon Trust Co., 229 IIl. 486,82 N. E. 418 (1907) 8emble; Summers v. Smith, 127 Ill. 645, 21 N. E. 191 (1889) semble; Deboe v. Lowen, 8 B. Mon. 616 (Ky. 1848); Abbott v. Essex Co., 18 How. 202 (U. S. 1855) semble; Lyons v. Cotharin, 205 Mich. 476, 171 N. W. 406 (1919) semble; Gannon v. Pauk, 200 Mo. 75, 98 S. W. 471 (1906) semble; Gannon v. Albright, 183 Mo. 238, 81 S, W. 1162 (1904) semble; Pinkham v. Blair, 57 N. H. 226 (1876) semble; Van Middlesworth v. Schenk, 3 Hals. 29 (N. J. L. 1824) semble; Kennedy v. Kennedy, 5 Kutch. 185 (N. J. L. 1861) semble; Wardell v. Allaire, 1 Spanc. 6 (N. J. L. 1842) semble; Seddel v. Wills, 1 Spenc. 223 (N. J. L. 1843) scmble; Howell v. Howell, 1 Spenc. 411 (N. J. I. 1845); Groves v. Cox, 40 N. J. L. 40 (1878).

Fosdick v. Cornell, 1 Johns. 440 (N. Y. 1806) semble; Jackson v. Blanshan, 3 Johns. 292 (N. Y. 1808) ; Anderson v. Jackson, 16 Johns. 382 (N. Y. 1819) ; Pond v. Bergh, 10 Paige Ch. 140 (N. Y. 1843); Cutter v. Doughty, 23 Wend. 513 (N. Y. 1840); Dumond v. Stringham, 26 Bart. 104 (N. Y. 1857) ; Langley v. Heald, 7 W. \& S. 96 (N. Y. 1844) semble; Rapp v. Rupp, $6 \mathrm{~Pa} .45$ (1847) semble; Johnson v. Currin, $10 \mathrm{~Pa} .498$ (1849); Nicholson v. Bettle, $57 \mathrm{~Pa}$. 384 (1868); Ingersoll's Appeal, $86 \mathrm{~Pa} .240$ (1878); Stoner v. Wunderlich, $198 \mathrm{~Pa} .158,165,47$ Atl. 945, 949 (1901) (realty) scmble; Mebus' Estate, 273 Pa. 505, 516, 117 Atl. 340, 345 (1922) (realty to be sold) semble; DeTreville v. Ellis, 1 Bailey Eq. 40 (1827); Selman v. Robertson, 46 S. C. 262 (1895) ; Lewis v. Claiborne, 5 Yerg. 369 (Tenn. 1821); Brown v. Hunt, 12 Heisk. 404 (Tenn. 1873).

If there is a gift over to one for life after the gift on death without issue of the first taker, the gift is conditioned on a definite failure of issue. Ide v. Ide, 5 Mass. 500, 502 (1809) (land) semble; Stoner v. Wunderlich; Mebus' Estate, both supra; Higgenbotham v. Rucker, 2 Call. 265 (Va. 
jurisdictions where the courts have held the other way. ${ }^{37}$ But if the subject matter be personalty, this minority is very small..$^{\text {is }}$

(2) If the gift over be upon the first taker's "dying without leaving issue," the common law meaning still obtains in a bare majority of jurisdictions. ${ }^{79}$ If the subject matter is personalty, the restricted sense has been unanimously accepted..$^{80}$

1800) (personalty) semble. Contra: Newton v. Grifith, 1 Har. \& G. 111 (Md. 1827) (land).

If the gift over for life is followed by a remainder in fee, there is no presumption that a definite failure of issue is meant. Pennington v. Pennington, 70 Md. 418 (1889) (land). Contra: Stone v. Bradlee, 183 Mass. $165,170,66$ N. E. 708, 710 (1903) (land and personalty) semble; Todd v. Armstrong, $213 \mathrm{~Pa} .570,62$ Atl. 1114 (1906) (real estate).

77 Caulk v. Caulk, 3 Pennew. 528, 52 Atl. 340 (Del. 1902); Huxford v. Milligan, 50 Ind. 542 (1875); Newton v. Griffith, 1 Har. \& G. 111 (Md. 1827); Farrar v. Christy, 24 Mo. 453 (1857) semble; Hoxton v. Archer, 3 G. \& J. 199 (Md. 1831) ; Secquil v. Moore, 1 Coxe 386 (N. J. L. 1795); Haines v. Witmer, 2 Yeates 400 (Pa. 1798); Duer v. Boyd, 1 S. \& R. 203 (Pa. 1814) ; Caskey v. Brewer, 17 S. \& R. 441 (Pa. 1828); Clark v. Balser, 3 S. \& R. 470 (Pa. 1817) semble; Burkart v. Bucher, 2 Binn. 455 (Pa. 1810) semble; Sharp v. Thompson, 1 Whart. 139 (Pa. 1836); Hefiner v. Knepper, 6 Watts 18 (Pa. 1837); Braden v. Cannon, $24 \mathrm{~Pa} .168$ (1854); Wall v. Maguire, $24 \mathrm{~Pa} .248$ (1855); Rancel v. Creswell, $30 \mathrm{~Pa} .158$ (1858) semble; Doyle v. Mullady, $33 \mathrm{~Pa} .264$ (1859); Moody v. Snell, $81 \mathrm{~Pa} .359$ (1876); Hope v. Rusha, $88 \mathrm{~Pa} .127$ (1878); Reinoehl v. Shirk, $119 \mathrm{~Pa} .108$, 12 Atl. 806 (1888); Borrough v. Foster, 6 R. I. 534 (1860); Brownell v. Brownell, 10 R. I. 509 (1873); Bells v. Gillespie, 5 Rand 273 (Va. 1827); Broaddus v. Turner, 5 Rand 308 (Va. 1827).

79 Gray v. Gray, 20 Ga. 804 (1856); Huxford v. Milligan, 50 Ind. 542 (1875); Nowlin v. Winfree, 8 Gratt. 346 (Va. 1852). Contra: Williams v. Graves, 17 Ala. 62 (1849); Russ v. Russ, 9 Fla. 105, 113 (1860) semble; Pinkham v. Blair, 57 N. H. 226 (1876) semble; Kimball v. Penhallow, 60 N. H. 448 (1881) semble; Moffat v. Strong, 10 Johns. 12 (N. Y. 1813); Norris v. Beyea, 13 N. Y. 273,280 (1855) semble; Mloreland v. Arajors, 1 Murph. 48 (N. C. 1805) semble; DeTreville v. Ellis, 1 Bailey Eq. 40 (S. C. 1827); Stevens v. Patterson, 1 Bailey Eq. 42 (S. C. 1829); Brown v. Hunt, 12 Heisk. 404 (Tenn. 1873).

${ }^{79}$ Ide v. Ide, 5 Mass. 500 (1809) semble; Hawley v. Northampton, 8 Mrass. 3 (1811) ; Hurlburt v. Emerson, 16 MIass. 241 (1819); Nightingale v. Burrell, 15 Pick. 104 (Mass. 1833); Mlalcolm v. Malcolm, 3 Cush. 472 (Mass. 1849); Farrar v. Christy, 24 MIo. 453 (1857); Osborne v. Shrieve, 3 Mas. 391 (C. C. D. R. I. 1824) ; Burfoot v. Burfoots, 2 Leigh. 119, 132 (Va. 1830) semble; Paterson v. Ellis, 11 Wend. 259, 279 (N. Y. 1833) semble; Chetwood v. Winston, 40 N. J. L. 337 (1878); Bibb v. Bibb, 79 Als. 437 (1885) semble; Caulk v. Caulk, 3 Pennew. 528, 52 Atl. 340 (Del. 1902) scmble; Scofield v. Litchield, 116 Me. 440, 102 Atl. 240 (1917); BIcCarthy v. Walsh, 123 Me. 157, 122 Atl. 406 (1923).

Contra: Beresford v. Elliott, 1 Des. Eq. 183 (S. C. 1790); Robeson v. Cochran, 255 Ill. 355, 358, 99 N. E. 649 (1912) semble; Morehouse v. Cotheal, 2 Zab. 430, 440 note (N. J. L. 1850); Daniel v. Thomson, 14 B. Mron. 663 (Ky. 1854); Smith v. Kimbell, 153 Ill. 368, 38 N. E. 1029 (1894).

80 Beresford v. Elliott, 1 Des. Eq. 183 (S. C. 1790); Dunn v. Bray, 1 Call 294 (Va. 1798) ; Atwell's Executors v. Barney, 1 Dud. 207 (Ga. 1831) semble; Clapp v. Fogleman, 1 D. \& B. Eq. 466 (N. C. 1836); Robards v. 
(3) If the gift over upon death without issue is expressed to take effect "after his decease" or "at his death," the weight of authority holds both as to land and personalty that the common law presumption is rebutted.81

It is to be regretted that all the American judges have not been able to anticipate the legislatures in holding that our social structure justifies a departure from the common law of England, and a holding that in all these categories there is a presumption of a definite failure of issue.

A number of American cases without sufficient reason confine a gift over on death without issue to such death prior to that of the testator who created the limitations. These decisions cut across the authorities hitherto discussed without paying any attention to them. Before analyzing this anomalous line of authority, it is necessary to consider the English law.

(1) If there is an immediate gift to $A$ absolutely and a gift over "in case of his death," or "if he die," such gift over will only be effective if $A$ dies before the testator. ${ }^{82}$

(2) If there is a gift to $X$ for life and then to $A$ absolutely, a gift over "in case of $A$ 's death," or "if he die," will take effect only if $A$ die prior to the vesting in possession of his interest. ${ }^{\text {s }}$

(3) If there is a gift to $A$ absolutely with a gift over "if $A$ die without issue him surviving" (or unmarried, or without children, etc.), the gift is not confined to the death of $A$ before that of the testator. ${ }^{84}$

(4) Likewise, if, in the preceding case, there be a prior life estate to $X$, the gift over takes effect upon the death of $A$ without issue him surviving at any time, whether before or after the death of the testator or of the life tenant.85

(5) If in the last two preceding cases there are gifts over, first, "if $A$ die without issue him surviving," and second, "if $A$ die with issue him surviving," all possibilities after $A$ 's death are

Jones, 4 Ired. L. 53 (N. C. 1843); Ladd v. Harvey, 21 N. H. 514 (1850); Robert v. West, 15 Ga. 122 (1854) semble; Woodward v. Woodward, 1 Green 83 (N. J. Eq. 1863); Allender v. Sussan, 33 Md. 11 (1870).

${ }^{81}$ Atwell's Executors v. Barney, Dud. 207 (Ga. 1831) (personalty); Sinnickson v. Snitcher, 2 Green 53 (N. J. L. 1833) (land); Downing v. Wherrin, 19 N. H. 9 (1848) (land); Whitford v. Armstrong, 9 R. I. 394 (1870); Swinburne, Petitioner, 16 R. I. 208 (1888) (realty and personalty); Wilson v. Wilson, 46 N. J. Eq. 323 (1890) (land); Parkhurst v. Harrower, 142 Pa. 432 (1891) (land) semble; Hall v. Brownlee, 164 Ind. 238, 72 N. E. 131 (1904) (personalty); Ide v. Ide, 5 Mass. 500, 502 (1809) (land) semble. But see Tinsley v. Jones, 13 Gratt. 289, 293 (1856) (land).

82 Treobald, op. cit. sipra note 3 , at 742 .

83 Ibid. 744.

84 Ibid. 745.

${ }^{85} \mathrm{Ibid}$. 746. The leading case is O'Mahoney v. Burdett, L. R. 7 H. L. 388 (1875). 
taken care of, and, therefore, the gifts over are construed to take effect if $A$ die before his interest vests in possession. ${ }^{80}$

It is with reference to the situations described in paragraphs 3,4 , and 5 that there are a number of American decisions ${ }^{\text {ar }}$ the conclusions of which are not only at variance with the correct results in England indicated above, but which also confuse the facts in paragraphs 3,4 , and 5 with those in paragraphs 1 and 2 . The problem has frequently been presented in this country in the case of a gift over simply upon $A$ 's "death without issue." Suppose, for instance, the view is taken that in a gift over "on $A$ (the first taker) dying with issue," "dying without issue" means dying without issue prior to the testator, the question still remains to be decided whether, if $A$ dies before the testator, and leaves a child who dies childless before the testator, the contingency has in fact happened. Yet many of our courts have dealt with this situation as if it had no relation whatever to the question as to whether the gift over was upon definite or indefinite failure of issue in the sense discussed in the early part of this article. Almost invariably no mention is made of this aspect of the case.

\section{ALABAMA}

Prior to the enactment of Section 1302 of the Alabama Code of 1852, which construed a gift over on "failure of issue" as a gift conditioned on such failure at the death of the first taker, the phrase imported an indefinite failure of issue. ${ }^{8 s}$ If the gift over was to some one described as "surviving," a definite failure was meant.89 But a gift over without leaving issue, at least as to land, did not, in and of itself, limit the generality of the phrase. ${ }^{00}$

In Smith v. Smith,, there was a gift over on death without children surviving the first takers, and the court held, upon the authority of the Indiana and Pennsylvania decisions, that the contingency was confined to the death of the testator. In Burleson $v$. Mays," where the gift over was on death "without leaving any lawful heir," the court held that "heir" meant "children"

86 THEOBAID, op. cit. supra note 3, at 748; KaLEs, op. cit. supra note 2, § 532; Updegrafi, Some Effects of the District Code Provisions Dispensing With Words of Inheritance (1914) 14 GEo. L. REv. 253-256.

${ }^{87}$ See Note (1909) 25 L. R. A. (N. S.) 1045.

$8 s$ Darden's v. Burns, 6 Ala. 363 (1844) (personalty); Simmons v. Augustin, 3 Port. 69, 103 (Ala. 1836) (Iand) semble; MeGrav v. Davenport, 6 Port. 319 (Ala. 1837) (personalty) semible.

89 Williams v. Graves, 17 Ala. 62 (1849) (personalty).

90 Bibb v. Bibb, 79 Ala. 437 (1885) (land-involved the construction of a will drawn in 1839).

91139 Ala. 406, 36 So. 619 (1903).

92189 Ala. 107, 66 So. 36 (1914). 
or "issue," and it followed Smith v. Smith. ${ }^{\text {s }}$ If there is a life estate preceding the gift cut short by the conditional gift over, such condition is confined to the life of the life tenant."

\section{CONNECTICUT}

A few early Connecticut cases on estates tail by implication from a gift over on failure of issue would seem to indicate that the common law rule was to be followed, and a general failure of issue was prima facie intended. But the significance of these cases is greatly weakened by the extraordinary and unprecedented holding in Hudson $v$. Wadsworth ${ }^{05}$ that an estate tail by implication may arise although the gift over is on definite failure of issue..$^{96}$ And against the inference in favor of the common law doctrine, a number of cases justify the conclusion that "where the phrase 'dying without issue' is held not to refer particularly to death before the testator, the phrase will be held to refer to the taker's own death, and not to an indefinite failure of issue in the future." 97

In Holmes v. Williams, ${ }^{98}$ there was a devise of land to Williams and his heirs on condition that he pay Holmes $£ 200$ when he arrives at full age, but if Williams die without issue, then to Holmes and six others. It was held that the gift over was on Williams' death without issue prior to full age.90 In Morgan $v$. Morgan, ${ }^{100}$ where the gift over upon death without issue was to the brothers of the first taker, and there was no condition that they survive him, the court seemed to think that a personal provision for them was meant, and it therefore restricted the condition to a definite failure of issue. The attitude of the court, however, was against the general common law meaning. ${ }^{01}$ And in

${ }^{93} \mathrm{Cf}$. O'Connell v. O'Connell, 196 Ala. 224, 72 So. 81 (1916) oomble, where almost all contingencies were provided for, but such fact was not made the basis for the opinion.

A similar point was directly passed upon, with the same result, in Spira v. Frankel, 210 Ala. 27, 97 So. 104 (1923), where there was a gift over if the first taker "should die leaving no issue."

${ }^{94}$ Cf. Boshell v. Boshell, 218 Ala. 320,118 So. 553 (1928) (the condition held, upon a special context, to be effective no matter when it occurred); Reynolds v. Reynolds, 208 Ala. 674, 95 So. 183 (1923) (the condition was if he "die childless.")

858 Conn. 348 (1831).

oc See Turrill v. Northrop, 51 Conn. 33, 38 (1883); Mahoney v. Mahonoy, 98 Conn. 525, 536, 120 Atl. 342, 347 (1923).

87 Creaveland, HewitT AND ClaRK, op. cit. supra note 71, at 529. Tho writer has relied upon the full collection of cases and their accurate statement in this work. Ibid. 528-529, and Supplement (1929) 203, 213.

981 Root 332 (Conn. 1791).

99 Accord: Williams v. Dickerson, 2 Root 191 (Conn. 1795) (land).

1005 Day 517 (Conn. 1813).

201 Ibid. 521, 522. 
the following year the court rejected Chadock v. Couley, ${ }^{102}$ and held that, where there was a devise of land after failure of issue to "surviving brethren," a definite failure of issue was intended. ${ }^{103}$ Later, Bullock v. Seymour ${ }^{100}$ and Clarke 2'. Terry ${ }^{205}$ settled the law in favor of the restricted construction. ${ }^{100}$

The first decision cited for fettering to the death of the testator a gift over on such a condition is Phelps v. Robbizs. ${ }^{10 r}$ But this case turned entirely upon the special context of the will in question. ${ }^{108}$ of more significance is White $v$. White. ${ }^{103}$ In restricting the generality of the phrase to the death of the testator, the court relied upon gifts over upon the death of the first taker, ${ }^{210}$ which are not in point, and also upon the special context. There were dicta to a similar effect in Phelps v. Phelps ${ }^{112}$ and in Stone v. McEckron. ${ }^{112}$ Johnes $v$. Beers ${ }^{113}$ went upon a special context in the will in question. The leading case, however, is Lavvlor $v$. Holohan. ${ }^{114}$ This seems to be a solid decision to the restrictive effect, but, as it relies upon the cases above cited, which by no means settle the law for Connecticut, its force is weakened. Indeed, Chesebro v. Palmer, ${ }^{115}$ relying upon Turrill v. Northrop, ${ }^{110}$ went the other way. Lawlor $v$. Holohan was accordingly doubted in Butler v. Flint. ${ }^{117}$ Nevertheless it must now be considered law.118

No case has been found in Connecticut where there is a gift to $A$ for life, and then to $B$ and his heirs, but if $B$ die without

102 Supra note 25.

103 Couch v. Gorham, 1 Conn. 36 (1814).

10433 Conn. 289 (1866).

10534 Conn. 176 (1867).

106 Mfay this result not be due to the fact that Connecticut "jurisprudence was affected by the English law, more because the Colonists had imbibed its spirit where it was good and suited to their needs, than' because they directly copied or considered as in force any particular portion of it?" Cleaveland, HewitT, aNd Clark, op. cit. siupra note 71, at 921.

10740 Conn. 250 (1873).

108 Ibid. 270.

10852 Conn. 518 (1885).

110 Ibid. 521.

11155 Conn. 359 (1887).

11257 Conn. 194 (1889).

11357 Conn. 295 (1889).

114 70 Conn. 87 (1897).

11568 Conn. 207 (1896).

11651 Conn. 33 (1883).

11791 Conn. 630, 101 Atl. 19 (1917).

.118 Walsh v. McCutcheon, 71 Conn. 283, 41 Atl. 813 (1898); Hull v. Holmes, 78 Conn. 362, 62 Atl. 708 (1905); Rudlein v. Rand, 88 Conn. 292, 91 Atl. 198 (1914); Hull v. Hull, 101 Conn. 481, 126 Atl. 699 (1924) ; Burnham v. Burnham, 101 Conn. 529, 126 Atl. 704 (1924); see Cleavelasd, HEWITT AND Clark, op. cit. supra note 71, at 528 and Supplement (1929) 203. 
issue, to $C$ and his heirs, and where the question of fettering the condition to the death of $A$ has been clearly involved. Probably such an event would not be chosen by the court in preference to the death of the testator. ${ }^{119}$

\section{GEORGIA}

The early Georgia cases interpreted "dying without issue" as referring to an indefinite failure of issue. ${ }^{220}$ In Harris v. Smith, ${ }^{221}$ it was stated that the court, on slight evidence, would find a definite failure of issue. But the court not long after suggested in a case which apparently involved real and personal property that a gift over to persons "surviving" had no such effect.122 Nevertheless, if the gift over is "at the death" of the first taker, a definite failure of issue was held to exist in Atwell v. Barney. ${ }^{120}$ And there is a dictum that a death on "not leaving issue" has the same effect as to personalty. ${ }^{224}$ A statute similar to the New York act restricted the generality of the earlier decisions to a definite failure of issue. ${ }^{125}$

Cases on the question of whether the contingency of "dying without issue" should be confined to the period of distribution are in conflict. The weight of authority, however, seems to be in favor of such restriction. The early case of Bailey $v$. Ross 120 favors the period of distribution, although the court relied on the special context. And Sumpter v. Carter ${ }^{127}$ confines the condition to the death of the life tenant. Starnes v. Sanders ${ }^{128}$ is to the same effect. Moore v. Cook ${ }^{129}$ suggests that, where there is no life estate, words of survivorship are to be referred to the death of the testator, unless the contrary appears. Two other cases tend to hold that the condition refers to the death of the first taker at any time. ${ }^{130}$ No distinction seems to be taken between real and personal property.

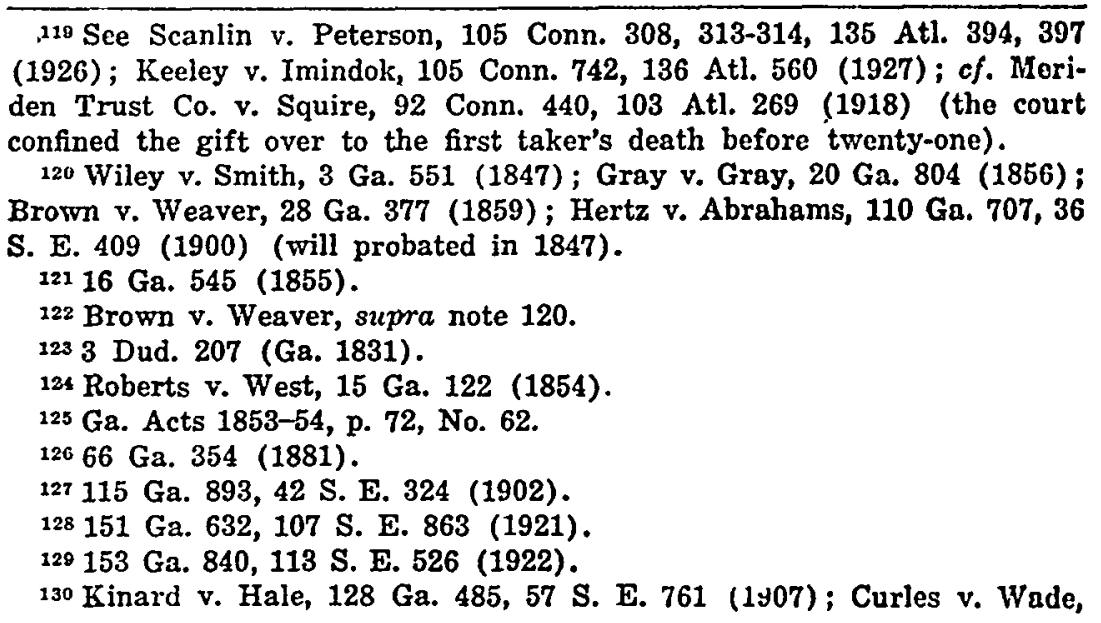




\section{ILLINOIS}

The Supreme Court of Illinois has held that, if there was a provision that the first taker die "without leaving issue," a definite failure of issue was meant. ${ }^{132}$ So also in the case of real estate if the gift over was to the survivor "of two devisees." 233 Apart from interests subject to an estate tail, the court has never held a future interest limited to take effect upon an indefinite failure of issue. In Lunt v. Lunt ${ }^{133}$ and in Strain v. Sweeny ${ }^{136}$ it has strained language to find a definite failure of issue. There are two dicta to the effect that the rule of the English Wills Act is in force. ${ }^{135}$ In two recent cases ${ }^{130}$ the court appears to have held that "die without issue" might be treated as meaning primarily "die without ever having had issue," even where the first taker had a fee and there was no independent gift to the issue or children of the first taker. ${ }^{237}$

Later Illinois cases, where there have been gifts over upon "death without issue" or "death without children," must now be considered from the point of view as to whether the contingency was on the death of the testator or preceding the death of the life tenant. Mr. Kales has considered these conditions, and we adopt his conclusion. ${ }^{138}$ Where the limitations are by will to $A$, simply with a gift or gifts over on $A$ 's death and one or more collateral contingencies, Mr. Kales says:

"If it be determined that $A$ takes only a life estate, then clearly 'die' refers to the death of the life tenant whenever that may occur. King v. King, 215 Ill. 100 (1905); Branson v. Bailey, 246 Ill. 490 (1910). Even where it is determined that $A$ takes a fee or an absolute interest the settled rule now is that

151 Ga. 142 , 106 S. E. 1 (1920); cf. Hill v. Terrell, 123 Ga. 49, 51 S. E. 81 (1905).

131 Smith v. Kimbell, 153 Ill. 368, 38 N. E. 1029 (1894); Hinricksen v. Hinricksen, 172 Ill. 462, 50 N. E. 135 (1898); Mletzen v. Schopp, $202 \mathrm{III}$. 275, 67 N. E. 36 (1903); Robeson v. Cochran, 255 Ill. 355, 99 N. E. 649 (1912) ; Morris v. Phillips, 287 Ill. 633, 122 N. E. 831 (1919); see KrLES, op. cit. supra note $2, \S 545$, n. 65.

132 Waldo v. Cummings, 45 Ill. 421 (1867); Summers v. Smith, $127 \mathrm{ml}$. 645, 21 N. E. 191 (1889); Hinricksen v. Hinricksen, supra note 131; Arnold v. Alden, 173 Ill. 229, 50 N. E. 704 (1898); cf. Johnson v. Johnson, 98 III. 564 (1881) ; Silva v. Hopkinson, 158 Ill. 386, 41 N. E. 1013 (1895).

133108 Ill. 307 (1891).

134163 IIl. 603,45 N. E. 201 (1896).

${ }_{135}$ Summers v. Smith, supra note 132, at 650-651, 21 N. E. at 192; Smith

v. Kimbell, supra note 131 , at 376,38 N. E. at 1031 .

${ }^{136}$ Stafford v. Read, 244 Ill. 138, 91 N. E. 91 (1910); Kendall v. Taylor, 245 Ill. 617,91 N. E. 644 (1910).

${ }^{137}$ Cf. Field v. Peoples, 180 Ill. 376,54 N. E. 304 (1890); Mrorris v. Phillips, supra note 131 , at 640,122 N. E. at 834 .

${ }^{138}$ KALES, op. cit. supra note $2, \S \S 531-534$. 
prima facie 'death' refers to death at any time either before or after the testator's death. Blackstone v. Althouse, 278 Ill. 481 (1917) ; Ashby v. McKinlock, 271 Ill. 254 (1916) ; Wilson v. Wilson, 261 Ill. 174 (1913); Brenock v. Brenock, 230 Ill. 519 (1907) ; Crocker v. Van Vlissinger, 230 Ill. 225 (1907) ; Carpenter v. Sangamon Trust Co., 229 Ill. 486 (1907) ; Fifer v. Allen, 228 Ill. 507 (1907) ; Bradsby v. Wallace, 202 Ill. 239 (1903); Thomas v. Miller, 161 Ill. 60 (1896) ; Smith v. Kimbell, 153 III. 368 (1894); Summers v. Smith, 127 Ill. 645 (1889)." 180

Clark $v$. Leavitt ${ }^{140}$ is to the same effect.

Where there is a gift to $X$ for life, and then to $Y$ absolutely, with a gift over on $Y$ 's death and one or more collateral contingencies, the effect is doubtful. In Lachenmyer $v$. Gehlbach, where the limitation was to $Y$ and the gifts exhausted all possibilities, the court restricted the contingencies to the death of the life tenant. ${ }^{142}$ Where there was a single gift over, death at any time was meant. ${ }^{143}$ But Sheley $v$. Sheley ${ }^{144}$ misunderstood Lachenmyer v. Gehbach and held that, where there was only one contingency, the result should be the same as in that case. Sheley $v$. Sheley seems to have been approved in Ames $v$. Smith; ${ }^{145}$ Fulwiler v. McClucn; ${ }^{160}$ Morris v. Phillips; ${ }^{147}$ and Risser $v$. Ayres; ${ }^{14 s}$ and there was a dictum to the same effect in Drager v. McIntosh. ${ }^{148}$

\section{INDIANA}

In Indiana, until a comparatively recent date, the old common law was strictly adhered to. Indeed, the court went a little beyond the English judges, for an indefinite failure of issus vas held to be meant, with respect to real and personal property, even where the expression "death without issue" was coupled with a gift over to what was substantially "survivors" of living persons. ${ }^{150}$ But if the gift over was expressed to be after the death of the first taker, then a definite failure of issue was held

139 Ibid. § 531.

140330 Ill. 350,161 N. E. 751 (1928).

14266 Ill. 11, 107 N. E. 202 (1914).

142 Welch v. Crowe, 278 Ill. 244, 115 N. E. 859 (1917) and Kleinhaus v. Kleinhaus, 253 Ill. 620, 97 N. E. 1077 (1912) seem inconsistent with this holding.

${ }^{143}$ Garvin v. Carroll, 276 Ill. 478,114 N. E. 927 (1917).

144272 Ill. 95,111 N. E. 59 (1916).

145284 Ill. 63,119 N. E. 969 (1918).

146285 Ill. 174,120 N. E. 458 (1918).

1347 Supra note 131.

148306 Ill. 293, 137 N. E. 851 (1923).

140316 Ill. $460,466,147$ N. F. 433,436 (1925).

150 Huxford v. Milligan, $50 \mathrm{Md}$. 542 (1875). 
to be intended, even though the gift over was not to "survivors." 152

Before long, however, a gift over on death without issue was interpreted in Wright 2 . Charley ${ }^{152}$ as such death before the testator. This change seems to have been based upon New York and Pennsylvania cases holding that conditional gifts over upon the death of the first taker were confined to such death before the testator, and upon a failure to consider the distinctions taken in O'Mahoney $v$. Burdett. ${ }^{153}$ But Wright $v$. Charley has been followed. ${ }^{154}$ Indeed, the Indiana court confines the death without issue to the life of the testator even though there is a life estate prior to the gift of the ancestor. ${ }^{15}$ Had not Indiana followed New York and Pennsylvania in this broad application of the restricted construction, it would seem that the law of Indiana would have been that an indefinite failure of issue at any time was meant. ${ }^{156}$

IOWA

In Collins $v$. Collins, ${ }^{157}$ the Iowa court held that, where there was a devise in fee, the devisee to take on the death of the testator, coupled with a gift over in case the donee died without issue, the words referred to such death during the lifetime of the testator, and that if the devisee survived, he should take an absolute estate in fee simple, and that this rule applied to real and personal property. ${ }^{16 s}$ This rule was approved in Tarbell $v$. Smith ${ }^{159}$ and in Blain v. Dean. ${ }^{160}$ In Tarbell $v$. Smith one of the reasons given was that the gift over was void for repugnancy under the rule of Meyer $v$. Weiler. ${ }^{101}$ In both these cases the gift

151 Hall v. Brownlee, 164 Ind. 238, 72 N. E. 131 (1905).

152129 Ind. 257,28 N. E. 706 (1891).

153 Supra note 85; cf. Harris v. Carpenter, 109 Ind. 540, 10 N. E. 422 (1887) ; Heilman v. Heilman, 129 Ind. 59, 28 N. E. 310 (1891).

154 Antioch College v. Branson, 145 Ind. 312, 44 N. E. 314 (1896); Teal v. Richardson, 160 Ind. 119,66 N. E. 435 (1903); Clark v. Thieme, 181 Ind. 163, 103 N. E. 1068 (1914); Quilliam v. Union Trust Co., 194 Ind. 521,142 N. E. 214 (1924); of. Morgan v. Robbins, 152 Ind. $362,53 \mathrm{~N}$. E. 283 (1899) ; First Nat. Bank v. DePauw, 86 Fed. 722 (C. C. A. 7th, 1898); Fowler v. Duhme, 143 Ind. 248, 42 N. E. 623 (1896).

153 Borgner v. Brown, 133 Ind. 391, 33 N. E. 92 (1893); cf. Mroores v. Hare, 144 Ind. 573, 43 N. E. 870 (1896); Hoover v. Hoover, 116 Ind. 498, 19 N. E. 468 (1889).

${ }^{156}$ See Quilliam v. Union Trust Co., supra note 154, at 534, 142 N. E. at 218 .

157116 Iowa 703, 88 N. W. 1097 (1902).

158 The court cited Fowler v. Duhme, supra note 154.

159125 Iowa 388,101 N. W. 118 (1904).

160160 Iowa 708,142 N. W. 418 (1913).

101121 Iowa 51, 95 N. W. 254 (1903). 
over was of only such real and personal property as was leit by the prior devisee. Talbot $v$. Snodgrass, ${ }^{102}$ relying upon Meyer $v$. Weiler, decided that a gift over was void for repugnancy. In Tarbell $v$. Smith, on the other hand, the gift over was not of what was left, and, therefore, the decision is of no value.

Tarbell $v$. Smith contained a dictum that the contingency of "dying without issue" should be confined to the testator's death even though there was a preceding life estate. But in Dowd $v$. $S c a l l y{ }^{163}$ the court intimated that the condition would be allowed to operate when it occurred after the death of the testator and before the life tenant. In that case all contingencies after the death of the life tenant were provided for. ${ }^{104}$

\section{KENTUCKY}

Kentucky is one of the few jurisdictions which abandoned the common law presumption and adopted, about the middle of the nineteenth century, a presumption of definite failure of issue both as to real and personal property. ${ }^{165}$ This may have been due to the hostility shown in Kentucky to the English common law. ${ }^{100}$

In Harvey $v$. Bell, , $^{167}$ the testator devised his property in trust to his four grandchildren. He further provided that if any of them should "die without issue of his or her body living, the property devised to the one so dying should be equally divided between the remaining ones or their issue." A question arose as to the title to some of the land, which in turn depended upon the construction of the above quoted expression in the will. The court held that death without issue at any time was meant and not such death before the testator. It laid down four rules:

"1st. Where an estate is devised to one for life, with remainder to another, and, if the remainderman die without children or issue, then to a third person, the rule is that the words 'dying without children or issue' are restricted to the death of the remainderman before the termination of the particular estate.

"2d. Where property is devised to one or more infants, and is to be held by their trustees or guardians until they are twentyone years old, and then be turned over to them, or divided be-

162124 Iowa 681,100 N. W. 500 (1904).

183184 N. W. 340 (Iowa 1921).

16s Cf. Atchison v. Francis, 182 Iowa 37, 165 N. W. 687 (1917); Caslavks v. Caslavka, 194 Iowa 52, 188 N. W. 4 (1922); In re Clifton's Estate, 205 Iowa 913,218 N. W. 926 (1928).

- ${ }^{165}$ Black v. Cartmell, 10 B. Mon. 188 (Ky. 1849) semble; Northcut v. Whipp, 12 B. Mon. 65 (Ky. 1851); Moore v. Moore, 12 B. Mon. 651 (Ky. 1851).

${ }^{160}$ Gray, The Nature and Sources of the law (2d ed. 1921) $245 \mathrm{n}$. See KY. REv. STAT. (1852) c. $80, \S 9$, which enacts this presumption as to real estate.

${ }^{167} 118 \mathrm{Ky} .512,81$ S. W. 671 (1904). 
tween them, with the proviso that, if they die without issue, it shall go to the survivors, or, if all die, to a third person, it has been held that the limitation as to dying without issue is to be limited to a death in infancy before the period of distribution.

" $3 \mathrm{~d}$. Where, by the will, the devise is to a class, and the period of division is postponed, even where the devisees are not infants, it has been held that the limitation as to dying without issue must be confined to a death without issue before the period of division fixed by the will.

"4th. On the other hand, where there is no intervening estate, and no other period to which the words 'dying without issue' can be reasonably referred, they are held, in the absence of something in the will evidencing a contrary intent, to create a defeasible fee which is defeated by the death of the devisee at any time without issue then living." 1cs

The first rule had its origin in Bimey v. Richardson, ${ }^{160}$ where there was a bequest of real and personal property to the testator's wife during widowhood, and if she married the whole estate was to be equally divided among the testator's children, and if any of the children "should die without a lawful heir begotten of their body, then his or her part of the estate would be equally divided among my surviving children." In an action for some of the personal property the construction of the will was drawn in question. The court held that the testator intended a dying without issue prior to the wife's marriage. It has been pointed out that this result is entirely sound. ${ }^{170}$ The Kentucky case was based on the earlier English case of Galland v. Leonard, ${ }^{171}$ where the facts were substantially the same. Both cases may well stand upon the intention of the testator disclosed upon the face of the will to confine the contingency to the period of division, which is evidenced by his direction to divide the corpus. ${ }^{1: 2}$ Indeed it has been made clear in England that in a gift to $A$ for life and then to $B$, and if $B$ dies without issue, over, the gift over will take effect upon the death of $B$ at any time without issue. ${ }^{173}$ Rule 1 therefore, is based upon a misapprehension, and indeed is in principle inconsistent with the 4 th rule mentioned therein, where, in the absence of a life estate, there is no fettering condition to the period of division. ${ }^{174}$ But the rules in Harvey v. Bell are apparently still law in Kentucky. ${ }^{175}$

\footnotetext{
16s Ibid. 521-524, 81 S. W. at 674-675.

1695 Dana 424 (Ky. 1837).

170 Note (1924) 24 COL. L. REv. 512, 514.

1711 Swans. 161 (1818).

172 Accord: Boynton v. Boynton, 165 N. E. 489 (Miass. 1929).

173 O'Mrahoney v. Burdett, supra note 85; THEOBAxD, op. cit. supra note 3 , at 486 .

'17* See O'Mahoney v. Burdett, supra note 85; THEOBaLd, op. cit. supra note 3 , at 486 . The first rule has been ably criticized in Note (1924) 24 COL. I. REv. 512, 514-518.

175 1st Rule: Ferguson v. Thomasson, 87 Ky. 519, 9 S. W. 714 (1888);
} 


\section{MARYZAND}

The doctrine of the Maryland cases involving wills and deeds prior to 1862 was as strict, if not stricter, than the common law. The phrase "dying without issue" was interpreted to mean an indefinite failure of issue. ${ }^{176}$ If the gift over is to "survivors" of living persons, then Chadock $v$. Cowley ${ }^{177}$ is followed as to land."17" Although no decision is directly in point there seems to be a disposition to follow Roe $v$. Jeffrey. ${ }^{178}$

By Acts of 1862, c. 161, the expression "dying without issue" in a will was restricted to a definite failure of issue; and in Laws of 1866, c. 236 , the same provision was extended to gifts inter vivos.

Forsythe v. Lansing, 109 Ky. 518, 59 S. W. 854 (1900); Bradshaw v. Williams, $140 \mathrm{Ky} .160,130 \mathrm{~S}$ : W. 985 (1910); Jewell v. White, $166 \mathrm{Ky} .325$, 179 S. W. 212 (1915); White v. White, $168 \mathrm{Ky} .752,182$ S. W. 942 (1916) semble; Baker v. Thomas, $172 \mathrm{Ky} .334,189$ S. W. 215 (1916); Bonner v. Wedekind, $193 \mathrm{Ky} .743,237 \mathrm{~S}$. W. 394 (1922) ; Ensminger v. Grimes, $201 \mathrm{Ky}$. 494, 257 S. W. 19 (1923); Linton v. Hail, $201 \mathrm{Ky} .698,702,258$ S. W. 111 (1924) semble; Wilson v. Morrill, $205 \mathrm{Ky} .257,265 \mathrm{~S}$. W. 774 (1924); IJcWilliams v. Havely, $214 \mathrm{Ky} .320,283 \mathrm{~S}$. W. 103 (1926); Rankin v. Rankin, 227 Ky. 169, 12 S. W. (2d) 319 (1928).

$2 d$ Rule: Jones v. Moore, $96 \mathrm{Ky} .273,28$ S. W. 659 (1894); Linton v. Hail, 201 Ky. 698-702, 258 S. W. 111 (1924) semble; Howard v. Howard, $212 \mathrm{Ky} .847,280$ S. W. 156 (1926).

3d Rule: Linton v. Hzil, $201 \mathrm{Ky} .698-702,258 \mathrm{~S}$. W. 111 (1924) samble.

4th Rule: The court said, by way of dictum, that this rule only applied to a case of real property, and that if the subject matter were personal, the condition would be confined to the case of the testator. Harvoy v. Bell, supra note 167, at 526. On the whole this distinction seems to have been preserved in the rest of the cases. Calloway v. Celloway, $171 \mathrm{Ky}$. 366, $188 \mathrm{~S}$. W. 410 (1916) (real and personal property confined to denth of testator); Prewitt v. Prewitt, 178 Ky. 346, 198 S. W. 924 (1917) (real and personal property confingd to death of testator); Ruhe v. Lislo, 200 Ky. 520, $255 \mathrm{~S}$. W. 133 (1923) (realty confined to death of testator).

In Atkinson v. Kern, $210 \mathrm{Ky} .824,276 \mathrm{~S}$. W. 977 (1925) which was a case of real property, the court disapproved the cases just cited and followed the 4th rule in Harvey v. Bell. Other cases involving land approving the 4th rule are: Simpson v. Adams, $127 \mathrm{Ky} .790,106$ S. W. 810 (1908); Craig v. Williams, $179 \mathrm{Ky} .329,200 \mathrm{~S}$. W. 481 (1918); Linton v. Hail, 201 Ky. 698-702, 258 S. W. 111 (1924) semble; Ireland v. Cooper, $211 \mathrm{Ky} .823$, 277 S. W. 483 (1925) ; Laughlin v. Neeley, $223 \mathrm{Ky} .656,4$ S. W. (2d) 690 (1928). But in spite of the fact that Calloway v. Calloway, supra, was disapproved, it would seem that the distinction made in Harvey v. Boll between real and personal property still persists. See Ireland v. Cooper, $211 \mathrm{Ky} .323,326,277 \mathrm{~S}$. W. 483,484 (1925).

${ }^{176}$ Laidler v. Young, 2 H. \& J. 69 (Md. 1807) ; Tongue's Leasee v. Nutwell, 13 Md. 415 (1858); Comegys v. Jones, 65 Md. 317, 4 Atl. 667 (1886). 177 Supra note 25.

178 Newton v. Griffith, 1 Har. \& G. 111 (Md. 1827); Hoxton v. Archer, 3 G. \& J. 199 (Md. 1831).

${ }^{170}$ Supra note 26. See Newton v. Griffith, supra note 178, at 123, 124; Pennington v. Pennington, 70 Md. 418, 17 Atl. 329 (1889). 
In Fairfax v. Brown, ${ }^{130}$ a gift over on failure of issue living at death of first taker was confined to such death before the termination of the preceding estate to a life tenant. It should be noticed, however, that the gift over exhausted all the possibilities. In other words, there 'was a gift to issue, if there was issue, and a gift over if there was no issue left at the death of the first taker. In Hutchins v. Pearce, ${ }^{213}$ the condition was held to apply to the death of the first taker at any time, and Fairfax v. Broum was said to go upon a special context. In Bentz v. Maryland Bible Society ${ }^{182}$ and in Gerting $v$. Wells ${ }^{189}$ the gift was confined to the period of distribution, which was at the end of a period of years from the death of the testator. These two cases seem to be based upon Hammett $v$. Hammett. In that case there was a devise of real and personal property to the widow during life or marriage, then a gift to the children and a further bequest upon the death of the children. The court held that the condition was confined to the period of the life estate. The gift, however, was "on death" and not "on death without issue." In Lumplizin $v$. Lumpkin, ${ }^{185}$ there was a gift to the testator's children to take effect at his death, but in case any of them died without leaving lawful issue, then to the testator's wife and his surviving children. The arguments by counsel were full and able. The court held that the condition was confined to the testator's death and that if any child survived the testator that child took absolutely. That was said to be the law in Maryland. ${ }^{180}$ It is submitted, however, that the case is not of great value in that it relied upon Hammett v. Hammett ${ }^{187}$ and upon New York decisions. In Duering $v$. Brill, ${ }^{18 s}$ the same result was reached on the authority of Lumpkin v. Lumpkin. ${ }^{189}$ But in Duering $v$. Brill the gift exhausted all possibilities. Godwin v. Kemp ${ }^{100}$ went upon a special context of the will in question.

Where a life estate precedes the devise, which is divested upon the death of the taker without issue, such condition in Maryland seems to be confined to the duration of the lives of the testator and the life tenant.191

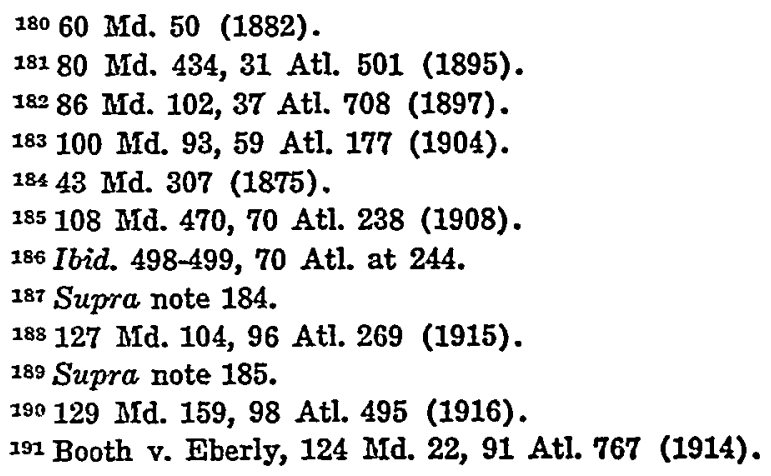




\section{MISSOURI}

Prior to $1845,,^{192}$ a gift over on failure of issue meant an indelinite failure of descendants. ${ }^{103}$ An early dictum indicates that it is immaterial that the gift over is expressed to some one "surviving" the first taker. ${ }^{194}$ But later dicta are the other way. ${ }^{103}$

In Yocum $v$. Siler, ${ }^{196}$ land was devised to $Y$ with a gift over if he died "without issue." $Y$ survived the testator and had legal issue living at his death. It was held that $Y$ took absolutely. It was assumed in the opinion that the gift over would have been effective irrespective of when the condition happened. But it was not necessary to the decision to pass upon this question. ${ }^{107}$ Gannon $v$. Pauk ${ }^{198}$ has a dictum to the same effect. Naylor $v$. Godman; ${ }^{199}$ Union Trust Co. v. Curby; ${ }^{200}$ and Hartnett $v$. Langan ${ }^{201}$ go upon special language in the will showing a period of division to which death without issue should be referred. ${ }^{202}$

The earliest case confining death without issue to the death of the testator is Henderson v. Calhoun, ${ }^{203}$ which relies solely on cases holding a presumption in general of early vesting of all kinds of future interests. Huntington Real Estate Co. v. Megaree ${ }^{204}$ involved a gift over on death with children, which was held upon the authority of Henderson $v$. Calhoun to become absolute upon the testator's death. The leading case is Owens $v$. Men and Millions Movement, ${ }^{205}$ where a gift over upon death "without leaving any issue". was confined to such death before the testator. No Missouri cases were relied upon, but the court cited and followed decisions from Illinois, Pennsylvania, Kentucky, Iowa, Maryland, Indiana and New York. The court cited the Statute of $1845,{ }^{206}$ which presumed a definite failure of issue, and held it inapplicable. ${ }^{207}$ This case was followed in Ewart $v$.

192 Mo. Rev. Stat. (1845) c. $32, \S 6$ presumed a definite failuro of issue. 103 Vaughn v. Guy, 17 Mo. 429 (1853); Farrar v. Christy's, 24 Mo. 453 (1857); Chism's v. Williams, 29 Mo. 288 (1860); see Hudson, Estates Tail in Missouri (1915) 1 U. OF Mo. BuLL. L. Sar. no. 1, p. 9.

194 Farrar v. Christy's, supra note 193.

195 Gannon v. Albright, 183 Mo. 238, 81 S. W. 1162 (1904) (land);

Gannon v. Pauk, 200 Mo. 75, 98 S. W. 471 (1906).

296160 Mo. 281, 61 S. W. 208 (1901).

197 Cf. Yocum v. Parker, 134 Fed. 205 (C. C. A. 8th, 1904).

198 Supra note 195.

198109 Mo. 543,19 S. W. 56 (1891).

200255 Mo. 393, 164 S. W. 485 (1914).

201282 Mo. 471, 222 S. W. 403 (1920).

${ }^{202}$ See also Welch v. Wagner, 232 S. W. 146 (Mo. 1921).

203183 S. W. 584 (Mo. 1916).

204280 Mo. 41, 217 S. W. 301 (1919).

205296 Mo. 110, 246 S. W. 172 (1922).

206 Supra note 192.

207 Owens v. Men and Millions Movement, supra note 205, at 121, $246 \mathrm{~S}$.

W. at 175 . 
Dalby, ${ }^{2+8}$ where it was also suggested, without being decided, that, if there had been a preceding life estate, the contingency would have been fettered to a happening before the death of the life tenant. ${ }^{n}$ The court relied for its decision not only upon Owens $v$. Men and Millions Movement, but also upon Northcutt $v$. McAllister, ${ }^{210}$ where the gift over was on death only, upon Huntington Real Estate Co. $v$. Megarec, ${ }^{212}$ and upon Henderson 2 . Calhoun. ${ }^{212}$ It thought furthermore that there was a suggestion in Naylor v. Godman ${ }^{213}$ in the same direction.

\section{NEW JERSEY}

In an early case in 1795, an estate tail was said to be created by a devise to the testator's three sons and their heirs with the proviso that "if either of my sons above named die without issue the premises given to him or them dying as aforesaid, shall go to him or them that survive." 214 Later cases, however, have clearly held that in a devise of land a gift over to persons described as "surviving" results in a definite failure of issue..215 It was likewise held, with regard to personalty and realty, that the word "living" added to a gift over upon death without issue had the same effect. ${ }^{216}$ And in the case of land it was also held that a definite failure was meant by the phrase "if he shall die without issue, that then at his decease." 217

In 1851 by statute New Jersey confined the presumption to a definite failure of issue. ${ }^{218}$ Meanwhile a long list of decisions was forming which restricted such a condition to the death of the testator $^{219}$ or to the death of the life tenant.220

208319 Mo. 108, 5 S. W. (2d) 428 .(1928).

209 Ibid. 120,5 S. W. (2d) at 432.

210297 Mo. 475, 249 S. W. 398 (1922).

211 Supra note 204.

212 Supra note 203.

213109 MTo. 543, 551, 19 S. W. 56, 58 (1892).

214 Secquil v. Mloore, 1 Coxe 386 (N. J. L. 1795).

215 Van Middlesworth v. Schenk, 3 Halst. 29 (N. J. L. 1824); Wardell v. Allaire, 1 Spenc. 6 (N. J. L. 1842); Seddel v. Wills, 1 Spenc. 223 (N. J. L. 1843) ; Howell v. Howell, 1 Spenc. 411 (N. J. L. 1845); Kennedy v. Kennedy, 5 Dutch. 185 (N. J. L. 1861); Ackerman v. Vreeland, 1 DIcCart. 23 (N. J. Eq. 1861).

216 Wallington v. Taylor, Sax. 314 (N. J. Eq. 1831) (land); Woodward v. Woodward, 1 Green Ch. 83 (N. J. Eq. 1863) (personalty).

${ }^{217}$ Sinnickson v. Snitcher, 2 Green 53, 59 (N. J. L. 1833) (land).

218 N. J. Laws 1851, March 12, p. 218.

219 Yawger v. Yawger, 37 N. J. Eq. 216 (1883); Denise v. Denise, 37 N. J. Eq. 163 (1883) ; Barrell v. Barrell, 38 N. J. Eq. 60, 39 N. J. Eq. 603 (1884); Baldwin v. Taylor, 37 N. J. Eq. 78, 38 N. J. Eq. 637 (1884) semble; Burdge v. Walling, 45 N. J. Eq. 10, 16 Atl. 51 (1888); Snyder v. Taylor, 88 N. J. Eq. 513, 103 Atl. 396 (1918); cf. W'ilson v. Wilson, 46 N. J. Eq. 3221, 19 Atl. 132 (1890); Steinhart v. Wolf, 95 N. J. Eq. 132, 
In Wurts v. Page, ${ }^{221}$ there was a devise of shares to daughters to be paid on marriage, and to some sons at 21 and to the other sons at 22, and "in case of the decease of any of my said children without issue," then over. The court held that as to the daughters there was a gift over at their death, and as to the sons a gift over before the shares were payable.

In Pennington v. Van Houten, ${ }^{222}$ the testator devised all of his real and personal estate to his son, but ordered his executors to put the proceeds at interest and support the son until he attained 21 ; "but if my son Abraham should die having no children, then" over. The court held that the contingency upon which the gift over was limited was confined to the son's death under 21.

In Patterson v. Madden, ${ }^{223}$ there was a gift of land to the tes. tator's sons. He provided, however, that none of the land should be sold during the life of his wife. He further provided that if any of his sons "should die without leaving issue and leaving a widow," then over. The court held that Pennington $v$. Van Houten governed and that the condition upon which the gift over was limited was confined to the death of the sons before the testator's wife. It laid down two rules:

"First. If land be devised to $A$ in fee and a subsequent clause in the will limits such land over to designated persons in case $A$ dies without issue, and $A$ so dies, and the substituted devisees are in esse at his death, and there is no other event expressed in the will to which the limitation over can fairly be referred, then $A$ takes a vested fee which becomes divested at his death and vests in those to whom the estate is limited over.

"Second. Where there is an event indicated in the will other than the death of the devisee to which the limitation over is referable (for instance, the distribution of the testator's estate or the postponement of the enjoyment of the property devised until the devisee reaches the age of twenty-one or until the exhaustion of a prior life estate), such limitation over will be construed to

122 Atl. 886 (1923). But see Hampton v. Newkirk, 93 N. J. Eq. 270, 115 Atl. 656 (1921) ; Patterson v. Madden, 54 N. J. Eq. 714, 723, 36 Atl. 273 (1896); Ackerman v. Vreeland, supra note 215 , at 24 ; Wurts v. Page, 19 N. J. Eq. 365 (1869).

220 Wurts v. Page; Yawger v. Yawger, both supra note 219; Williamson v. Chamberlain, 10 N. J. Eq. 373 (1855); McDowell v. Stiger, 58 N. J. Eq. 125, 42 Atl. 575 (1899); Shimer v. Shimer, 60 N. J. Eq. 300, 24 Atl. 385 (1892); Keepers v. Fidelity Co., 56 N. J. L. 302, 28 Atl. 585 (1894); Patterson v. Madden, supra note 219; Dilts v. Clayhaunce, 70 N. J. Eq. 10, 62 Atl. 672 (1906); Michael v. Minchin, 90 N. J. L. 603, 101 Atl. 283 (1917) semble; Freund v. Freund, 91 N. J. Eq. 80, 110 Atl. 449 (1919); Davis v. Scharf, 99 N. J. Eq. 88, 133 Atl. 197 (1926); Schreve v. Wilkins, 82 N. J. Eq. 18, 87 Atl. 642 (1913) (following what is said to be the first rule in Patterson v. Madden).

221 Supra note 219.

2224 Halst. Ch. 745 (N. J. Eq. 1852).

${ }^{223}$ Supra note 220. 
refer to the happening of such event or to the death of the devisee, according as the court may determine from the context of the will and the other provisions thereof that the limitation clause is set in apposition to the event specified or is connected with the devise itself." 224

The court found the first rule followed in Ackerman v. Vreeland, ${ }^{225}$ and in the decision on one of the devises in WWurts $v$. Page, ${ }^{228}$ and the second rule followed in Williamson 2 . Chamberlain, ${ }^{227}$ and in the decision on another of the devises in W'urts $v$. Page.

It is to be noticed that the second rule above quoted does not indicate any prima facie presumption as to whether the condition is to be confined to the death of the life tenant or the death of the devisee at any time. In three later cases it is indicated that the former presumption is to be adopted and that in the absence of a special context the condition is confined to the death of the life tenant.228 And a similar result has been reached where there is a period of distribution in the future. ${ }^{220}$ But on the other hand, such condition has been interpreted as operating on the death of the first taker at any time, where there was only a slight special context to justify the result.230

The first rule in Patterson $v$. Madden is affirmed in Snyder $v$. Taylor. ${ }^{231}$ There seems to be no distinction made by the courts between real and personal property in all these cases.

\section{NEW YORK}

The early New York decisions on definite and indefinite failure of issue are discussed above in connection with the New York legislation. ${ }^{232}$

The law of New York on confining gifts over on failure of issue to the death of the testator or of a life tenant has been exhaustively reviewed elsewhere by Professor Updegraff, 233 and will therefore not be considered here.

\footnotetext{
224 Ibid. 723.

225 Supra. note 215.

226 Supra note 219.

227 Supra note 220.

228 Michael v. Minchin, supra note 220; Freund v. Freund, 91 N. J. Eq. 80,110 Atl. 449 (1919); Davis v. Scharf, 99 N. J. Eq. 88, 133 Atl. 197 (1926).

229 McDowell v. Stiger, 58 N. J. Eq. 125, 42 Atl. 575 (1899); Keepers

v. Fidelity Deposit Co., 56 N. J. L. 302, 28 Atl. 585 (1894).

230 Hampton v. Newkirk, 93 N. J. Eq. 270, 115 Atl. 656 (1921) ; Ambruster v. "Own Your Own Home" Ass'n, 97 N. J. Eq. 69, 127 Atl. 167 (1925).

23188 N. J. Eq. 513, 103 Atl. 396 (1918).

232 Supra at 338-339.

233 Updegrafi, op. cit. supra note 86, at 249-256.
} 


\section{NORTH CAROLINA}

The cases in North Carolina on wills and conveyances taking effect prior to the Act of 1827-28 show that whether the subject matter was real or personal property the common law rule of indefinite failure of issue was followed. ${ }^{234}$

In Hilliard $v$. Kearney, ${ }^{235}$ the case turned upon the construction of a will made in 1775 by which negroes were bequeathed to the testator's wife for life and after her death to be equally divided "among my five daughters, Mary, Sarah, Elizabeth, Drucilla and Nancy, and if either of them die without an heir, her part to be equally divided among her other sisters." The testator's wife and five daughters survived him. His wife died, then Mary died, and the negroes were divided between the four surviving daughters. Afterwards Sarah and Nancy died, leaving children. Then Elizabeth died without a child. The court, relying upon English cases, decided that as Elizabeth had survived the testator and the life tenant, her share had become absolute. It pointed out that where there was no prior gift to that which was to go over upon death without issue the contingency was to be confined to the life of the testator; but, "if there be an intermediate period between the death of the testator and the death of the legatee, at which the estate may fairly be considered absolute," that time will be adopted. In this case the children had survived both the testator and the life tenant, and it was unnecessary to decide as to whether the condition should be confined to the death of the testator or the death of the life tenant. But the court went on to discuss this question and found sufficient evidence upon the face of the will to fetter the condition to the period before the testator's death.

This doctrine in North Carolina, as elsewhere, seems an unconscious departure from the prior cases. Only a few years before, in Garland $v$. Watt, ${ }^{236}$ the court had taken such a condition generally. Nevertheless, where there was no life estate or period of division otherwise fixed, the rule of Hilliard $v$. Kearney was followed. ${ }^{237}$ Where the gift to the first taker was postponed until

234 Realty: Brown v. Brown, 3 Ired. L. 134 (N. C. 1842); Brantley v. Whitaker, 5 Ired. L. 225 (N. C. 1844); Cox v. Marks, 5 Ired. L. 361 (N. C. 1845); Hollowell ن. Kornegay, 7 Ired. L. 261 (N. C. 1847); Weatherly v. Armfield, 8 Ired. L. 25 (N. C. 1847).

Personalty: Bryson v. Davidson, 1 Murph. 143 (N. C. 1806); Davidson v. Davidson, 1 Hawks. 163 (N. C. 1820) ; Rice v. Satterwhite, 1 D. \& B. Eq. 69 (N. C. 1835) ; Ferrand v. Howard, 3 Ired. Eq. 381 (N. C. 1844) ; Porter v. Ross, 2 Jon. Eq. 196 (N. C. 1855).

235 Busb. Eq. 221 (N. C. 1853).

2364 Ired. L. 287 (N. C. 1844).

237 Vass v. Freeman, 3 Jon. Eq. 221 (N. C. 1857) ; Garrison v. Eborn, 3 Jon. Eq. 228 (N. C. 1857); Jenkins v. Hall, 4 Jon. Eq. 334 (N. C. 1858) 
he became of age, it was held, in accordance with the rule quoted above from Hilliard $v$. Keainey, that death before his arriva! at the age of 21 was meant. 238

Meanwhile, however, there was a strong line of authority greatly limiting the application of Hilliard 2 . Kearney. In Buchanan $v$. Buchanan, ${ }^{239}$ the testator gave all of his estate not otherwise disposed of by his will dated 1843 to his son, and provided that, "should Richmond die without a bodily heir, it is my will and desire that my son Andrew should have it all." The court held that the gift over was in operation after the death of the testator. The court considered that Hilliard v. Keamey was confined to a gift to a class where there was a gift over to the survivors if any member died without issue.2*0 It further said that the Statute of 1827, which was enacted after the date of the will of Hilliard $v$. Kearney, and which changed the common law presumption from an indefinite failure of issue to a definite failure of issue at the death of the first taker, prevented any further restriction upon the generality of the condition and compelled the construction that the death without issue of the first taker should mean such death at any time. The court was obliged to admit. that several of the cases following Hilliard v. Kcarney could not be justified upon the principle suggested in Theobald on Wills. The rule of Buchanan $v$. Buchanan has been followed and the condition held to mean death at any time, even though there was a prior life estate. ${ }^{211}$ In view of this interesting construction of the Statute of 1827 , it is odd to find the same judge a few months later, in Fields $v$. Whitfield, ${ }^{242}$ following Price v. Johnson and confining the condition to the period before the first taker reached the given age.

Buchanan $v$. Buchanan received a fresh impetus from Patter-

semble; Davis v. Parker, 69 N. C. 271 (1873) ; Burton v. Conigland, 82 N. C. 99 (1880).

238 Burton v. Conigland, supra note 237.

Accord: Fields v. Whitfield, 101 N. C. 305,7 S. E. 780 (1888); Price v. Johnson, 90 N. C. 592 (1884) semble.

23999 N. C. 308,5 S. E. 430 (1888).

240 "Possibly, where there is a gift over, if any members of a class die yrithout issue, to the survivors, the gift over must take effect, if at all, before the time when the survivors are to be ascertained." THEOBaLD, op. cit. supra note 3 , at 746 .

241 Dunning v. Burden, 114 N. C. 34, 18 S. E. 969 (1894); Trull v. Railroad, 151 N. C. 545,66 S. E. 586 (1909) ; Perrett v. Bird, 152 N. C. 220, 67 S. E. 507 (1910); Elkins v. Seigler, 154 N. C. 374,70 S. E. 636 (1911); Hobgood v. Hobgood, 169 N. C. 485,86 S. E. 189 (1915); Kirlimen v. Smith, 175 N. C. 579,96 S. E. 51 (1918).

Rees v. Williams, 164 N. C. 128,80 S. E. 247 (1913); 105 N. C. 201, 81 S. E. 286 (1914), is to the same effect, although in that case there was no $\mathrm{r}$ rior life estate.

242 10 !. C. 305,7 S. E. 780 (1888). 
son v. McCormick,243 where an action to recover land turned upon the construction of a will which took effect in 1870. Therein the testator devised the land to his mother for life and after her death to his "nephews John D. and Clem Jowers to be divided equally between them. In case they, or either of them die without issue, it is my will that the property herein bequeathed shall go to the heirs of Archibald and Gilbert Patterson and to the surviving brother John D. or Clem Jowers, as the case may be, to be equally divided between them." The mother died in 1877; John D. died in 1904 without leaving any issue surviving him. It was held that as to John D.'s interest the gift over took effect. The opinion contains an exhaustive and able discussion of all the authorities. The case of Hilliard $v$. Kearmey was placed solely upon the ground that the will there involved took effect prior to the Act of 1827. The opinion in Patterson v. McCormick leaves nothing of the doctrine of Hilliard $v$. Kearney alive at the present time. ${ }^{44}$ Furthermore, it is hard to see how those cases which restricted the condition to a period of division fixed by the attrinment of the first taker of a given age can still be law, although they are not expressly overruled. ${ }^{245}$

It should be noted that when the gift over is not upon the condition of the first taker's dying without issue or children, but upon some other' event not coming within the Statute of 1827 , such as death with children surviving, two recent cases held that such condition is to be confined to the lifetime of the testator. ${ }^{246}$

\section{PENNSYLVANIA}

A leading case in Pennsylvania is Mickley's Appeal. ${ }^{241}$ By will proved in 1878, J. J. Mickley ordered his real estate to be sold and the proceeds to be added to the remainder of his personal property, which was then to be divided into equal shares. He gave one part thereof to each of his sons and daughters. A gift to a son read "to my son, Henry J. Mickley, or his heirs." The clause which gave rise to the present controversy was as follows:

243177 N. C. 448,99 S. E. 401 (1919).

244 Patterson v. McCormick has been approved in Love v. Love, $179 \mathrm{~N}$. C. 115,101 S. E. 562 (1919); Hines v. Reynolds, 181 N. C. 343,107 S. E. 144 (1921); Alexander v. Fleming, 190 N. C. 815,130 S. E. 867 (1925); American Yarn Co. $r$. Dewstoe, 192 N. C. 121, 133 S. E. 407 (1926). In all of these cases there was a prior life estate.

245 Burton v. Conigland; Fields v. Whitfield; Price v. Johnson, all supra' note 238.

246 Goode v. Hearne, 180 N. C. 475,105 S. E. 5 (1920); Dupree v. Daughtridge, 188 N. C. 193,124 S. E. 148 (1924).

247 $92 \mathrm{~Pa} .514$ (1880). 
"Fourth. I direct that if either of my sons should die without leaving issue living at the time of his death, the share given to such son shall pass to and be divided among such of my children as may be then living, and to the issue of such as may be dead, such issue, however, taking only the share of their parent. In the event of the death of either of my said children without issue living at the time of his or her death, I direct that in the distribution of the share of such child as aforesaid, the portion thereof allotted to each of my daughters shall be held in trust in the same manner as directed in the provision hereinbefore made for them." 248

The testator left surviving him three sons and three daughters, all of whom were living at the time of the litigation. The auditing judge held that the sons took each a life interest. Upon appeal the judgment was remanded to the Orphans' Court. That court decreed that the sons took absolute interests. An appeal was taken to the Supreme Court, where the decree of the Orphans' Court was affirmed. Chief Justice Sharswood said:

"It is very clearly settled, both in England and in this state, that if a bequest be made to a person absolute in the first instance, and it is provided that in the event of death, or death without issue, another legatee or legatees shall be substituted to the share or legacy thus given, it shall be construed to mean death or death without issue before the testator. The first taker is always the first object of the testator's bounty, and his absolute estate is not to be cut down to an estate for life, or what is practically the same thing, to be subjected to an executory gift over upon the occurrence of the contingency of death or death without issue at any future period within the rule against perpetuities without clear evidence of such an intent: Caldwell v. Skilton, 1 Harris 152; Estate of Mary Biddle, 4 Casey 59; Karker's Appeal, 10 P. F. Smith 141; Fahrney v. Holsinger, 15 P. F. Smith, 388; McCullough v. Fenton, Id. 418. . . . In the English cases a distinction is made between devises of realty and bequests of personalty, which has not been recognized in this state." 210

In Caldwell $v$. Skilton, ${ }^{250}$ one of the cases cited by the court, there was a devise of land to the testator's wife for life, and then to the children and their heirs in equal shares, and in case of the death of any of the children its share was to go to its children, or if a child should die without issue, then to the surviving children and their heirs. The wife died before the testator. The defendant agreed to purchase the share of one of the children but refused to take a conveyance because a clear title could not be conveyed. It should be noted that the gifts over were in every event. This in substance reduces $A$ 's estate in fee to a life estate. In order to avoid an incongruity it was necessary to

218 Ibid. 515.

249 Ibid. 517-518.

$25013 \mathrm{~Pa} .152$ (1850). 
fetter the condition to the death of the testator. ${ }^{251}$ And the court, resting its decision on this ground, held that the grantor under the deed having survived the testator and the wife took an absolute interest and could convey a clear title.

In the second case cited, Estate of Biddle, ${ }^{252}$ a will gave property, apparently both real and personal, to Anne E. Biddle, the testatrix's daughter, and in the event of her daughter's "death without 'children," over to named persons. The question was whether Anne took an absolute estate or a life estate. The court held that she took an absolute estate, relying on Caldwell $v$. Skilton, and upon the special context. It is to be noted that the gift over did not include every event and therefore the case proceeded upon a mistaken idea of that case. Moreover, it was a dictum only.

In Karker's Appeal, ${ }^{253}$ land was devised to $A$ and his heirs, but if he should happen to die intestate and without issue, then over. It was held that $A$ took an absolute interest and the gift over was void as a gift'over on intestacy. The case is obviously no authority for Mickley's Appeal. Finally, Fahrney v. Holsinger ${ }^{254}$ went on the special context of the will.

Mickley's Appeal was not cited by the United States Supreme Court in a case from Pennsylvania, Brition v. Thornton, ${ }^{255}$ where after a devise to one E. A. Thornton there was a gift over if he died under age and without issue, and the Court held that the condition operated after the death of the testator.

Barber v. Pittsburgh Railway Co. ${ }^{250}$ was also a caso from Pennsylvania decided by the United States Supreme Court. The question was whether $A$ took an estate tail under a will effective in 1831, prior to the Act of 1883 making a fee presumptive, the Act of 1855 converting estates tail into estates in fee simple, and the Act of July 9, 1897, which presumed a definite failure from a gift over on death without issue. There was a devise to Amanda and "in the event of Amanda dying unmarried, and if married without offspring by her husband," then among the heirs of J. B. The Supreme Court of Pennsylvania in a prior ejectment action had given Amanda a fee, on the ground that the gift over was substitutionary. ${ }^{25 t}$ The Supreme Court of the United States, Mr. Justice Gray writing the opinion, held that it was not bound to follow the Supreme Court of Pennsylvania, for the reason that there was in Pennsylvania no settled rule

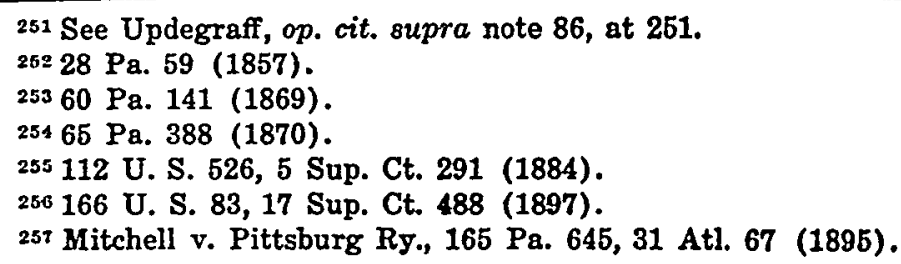


that "dying without issue" meant such death in the life of the testator only; and held that an indefinite failure of issue was meant. Mr. Justice Gray said :

"There is, indeed, a line of cases in that court, in which a devise over, after a devise in fee, has been held to be substitutionary, when expressed by such words as if the first taker die "without children"; (Biddle's Estate, (1857) 28 Penn. St. 59; McCormick v. McElligott, (1889) 127 Penn. St. 230;) or "without leaving issue living at the time of his death," (Mickley's Appeal, (1880) 92 Penn. St. 514; Stevenson v. Fox, (1889) 125 Penn. St. 568; King v. Frick, (1890) 135 Penn. St. 575; Morrison v. Truby, (1891) 145 Penn. St. 540;) or "intestate and without issue," (Karker's Appeal, (1869) 60 Penn. St. 141; Coles v. Ayres, (1893) 156 Penn. St. 197.) In none of these cases, however, was the devise so expressed that it could be construed as creating an estate tail." 258

Mr. Justice Gray further pointed out 259 that in Schoonmalier v. Stockton, ${ }^{260}$ and in Shutt $v$. Rambo,,201 where the expressions were respectively "die without heirs" and "die in the lifetime of the testator," a special context limited the gift over. In addition to the cases cited by Mr. Justice Gray, there were three cases where a definite failure of issue was intended and nothing was said about fettering the condition'to the testator's death. ${ }^{202}$

In Fitzwater's Appeal, ${ }^{263}$ the testator bequeathed personalty to his nephew for life, and after the nephew's death, to his son Frank, and "should said Frank Fitzwater son of my nephew, Jacob Fitzwater, die without issue," then over to other relatives. The court held that the son, upon surviving his father, took an absolute interest. It is to be noted that, as the case was one of personalty, no question of estate tail was involved. In Robinson's Estate, ${ }^{264}$ where the gift over was upon death without issue to "the surviving child," the condition was confined to the death of the testator in a case involving land and personalty.

Since Barber $v$. Pittsburgh Railway Company, ${ }^{205}$ there has been one case in which an estate tail by implication has been created by the gift over. ${ }^{206}$ In two cases ${ }^{207}$ involving controversies

258 Barber v. Pittsburgh, supra note 256, at 102, 17 Sup. Ct. at 492.

259 Ibid. 103, 17 Sup. Ct. at 492.

$20037 \mathrm{~Pa} .461$ (1860).

$26157 \mathrm{~Pa} .149$ (1868).

262 Snyder's Appeal, $95 \mathrm{~Pa} .174$ (1880) ("shall at any time die without issue"); Parkhurst v. Harrower, $142 \mathrm{~Pa} .432,21$ Atl. 826 (1891) ("at time of his son's death"); Estate of Miller, 145 Pa. 561, 22 Atl. 1044 (1891)

("die before he had any heirs").

26394 Pa. 141 (1880).

$261149 \mathrm{~Pa}$. 418, 24 Atl. 297 (1892).

265 Supra note 256.

260 Hannon v. Fliedner, 216 Pa. 470, 65 Atl. 944 (1907); cf. Dilworth v.

Schuykill Co., 219 Pa. 527, 69 Atl. 47 (1908).

267 Todd v. Armstrong, $213 \mathrm{~Pa}$. 570, 62 Atl. 1114 (1906); Waldron v. Wahl, 286 Pa. 237, 133 Atl. 252 (1926). 
over land, a definite failure of issue was found, and the result in Mickley's Appeal ${ }^{268}$ was not followed. In Mebus's Estate, ${ }^{200}$ the court said that a special context made the death of the first testator the time intended for the happening of the condition. And in Shearer v. Miller ${ }^{270}$ and Sharpless' Estate, ${ }^{271}$ in both of which land was involved, a special context confined the condition to the death of a life tenant whose estate preceded the one in question.

Mickley's Appeal was followed in cases involving land where the conditions were respectively "die unmarried and without issue"; ${ }^{272}$ and "living at death." ${ }^{273}$ In Flick v. Oil Co., ${ }^{274}$ involving a will of land, there was a gift over, if the first taker "depart this life without issue," to an other for life and then to six named persons, and Mickley's Appeal was again followed.

The same result was reached in two cases of personal property, in one of which the words "leaving" and "survivors" were used, ${ }^{275}$ and in the other of which the words were "the shares of any deceasing child leaving no lawful issue to increase the shares of the survivors." 278

\section{RHODE ISLAND}

Prior to the Rhode Island Statute of $1896{ }^{277}$ the law of Rhode Island was the common law rule of indefinite failure of issue. ${ }^{270}$ It made no difference that the gift over was to survivors, at least so far as land was concerned. ${ }^{220}$ Forth $v$. Chapman ${ }^{280}$ was also followed in regard to land where the gift over was upon "leaving no issue." ${ }^{281}$ The expression "after his death," however, probably had a qualifying effect, both as to real and personal

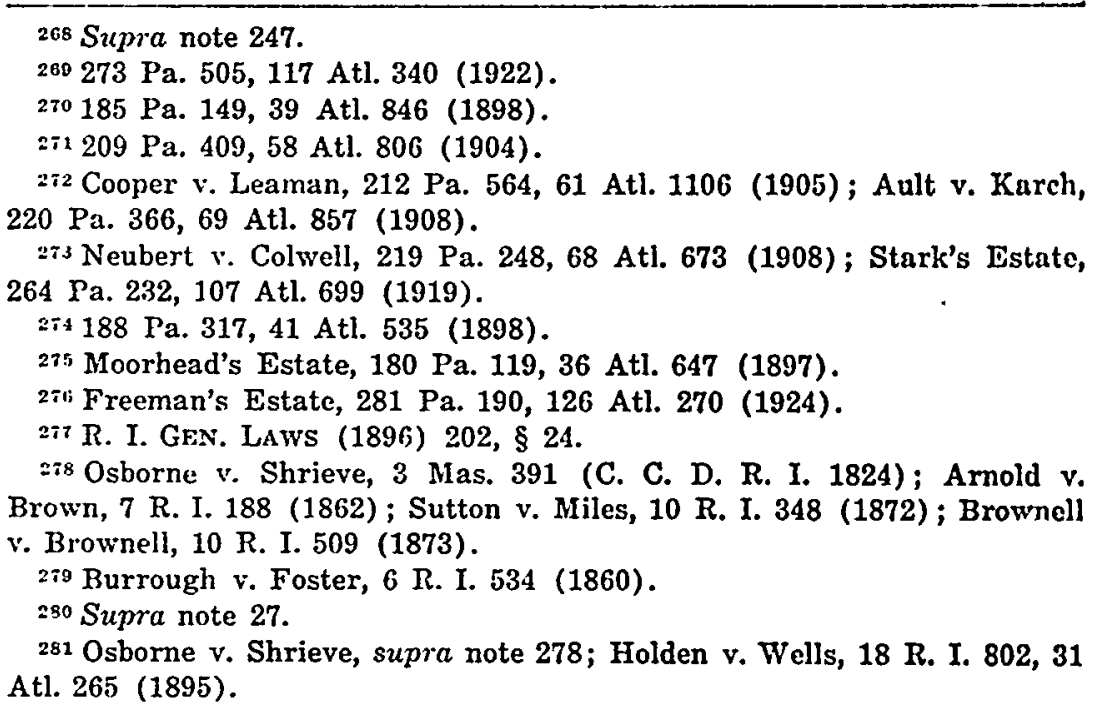


property. ${ }^{282}$ It is to be noted that an earlier case involving land held that there was an indefinite failure of issue, although the gift over was conditioned upon the words, "if he has no lawful issue after him." 283

Although Rhode Island maintained the orthodox rule until late in its legal history, in 1894 Harris v. Dyer ${ }^{281}$ confined the condition to the death of the testator. The testator, by a will of 1887, divided his realty among his children in equal shares and provided that "in case of the death of any of the six named heirs to the residue of my estate, without leaving lawful issue, the survivors will inherit the portion of the deceased party but in the case of any one of the six parties named leaving lawful issue, then they are to inherit the parents' portion." The question in the case was whether the devisee, who survived the testator, could convey a good title to the land. The court held that he could, upon the ground that the gifts over were conditioned upon events which were intended to happen before the death of the testator. The opinion relied upon English, Pennsylvania, New Jersey, and North Carolina cases, and to a slight extent upon the special context. It is to be noted that the gifts over embraced all contingencies, but this was not relied upon by the court. It is hard to reconcile this case with the opinion less than a year later in Holden v. Wells, ${ }^{285}$ where an indefinite failure of issue was held to exist with reference to a devise of land, and no question was raised in regard to confining the condition to the testator's death. Harris $v$. Dyer was followed by In re Johnson, ${ }^{\text {,es }}$ and approved in Newport Trust Co. v. Chappell. ${ }^{287}$

\section{SOUTH CAROLINA}

Prior to the Statute of $1853^{268}$ the gift over on death without issue imported a definite failure of issue. ${ }^{289}$ Slight changes appearing on the face of the will, however, resulted in the narrow

282 Swinburne, Petitioner, 16 R. I. 208, 14 Atl. 850 (1888) (personalty);

Wells v. Fairbanks, 6 R. I. 474 (1860) (realty).

283 Whitford v. Armstrong, 9 R. I. 394 (1870) ; cf. Lippett v. Hophins,

1 Gall. 454 (C. C. D. R. I. 1813).

The writer of the opinion in Swinburne, Petitioner, supra note 282, Durfee, C. J., was a member of the court which decided Whitford v. Armstrong, supra.

28418 R. I. 540, 28 Atl. 971 (1894).

2sj 18 R. I. 802, 31 Atl. 265 (1895).

286 23 R. I. 111, 49 Atl. 695 (1901) (land).

25ז 40 R. I. 983,101 Atl. 323 (1917) (personalty).

$28 s$ S. C. Stat. (1853) 298.

${ }^{280}$ Graham r. Moore, 13 S. C. 115 (1879); Mangum v. Piester, 16 S. C.

316 (1881) (both dealing with wills prior to 1853). 
construction of definite failure at the death of the first taker. ${ }^{200}$ Forth v. Chapman ${ }^{281}$ was followed as to realty and personalty. ${ }^{202}$ A gift over to "surviving" persons limited the gift, both real and personal property, to a definite failure of issue. ${ }^{203}$

During the first half of the nineteenth century there seemed no tendency in the South Carolina cases to confine the contingency of a gift over on failure of issue to the testator's death. In Yates v. Mitchell, ${ }^{204}$ where the contingency was "without leaving lawful begotten issue living at the time of his, her, or their death," such condition was taken generally. The cases of Vidal $v$. Verdier ${ }^{295}$ and Dehay v. Porcher ${ }^{206}$ clearly go upon the special context of the particular wills involved. Presley $v$. Davis, ${ }^{207}$ 'however, confined the following contingency to the death of the tesator: "if any should die or make their exit without lawful issue, then their portions are to be equally divided among the remainder of the aforesaid children," and decided that such condition should not be operative after the testator's death. The court relied upon Schoppert $v$. Gillam, ${ }^{208}$ where a gift over after a life estate to surviving children of a third person was held to mean children surviving the life tenant, on the authority of Cripps $v$. Wolcott..$^{200}$ Blum v. Evans ${ }^{300}$ held that a gift over on death without issue should be confined to the life of the testator's wife who took a prior life estate. But in Owings $v$. Wood, ${ }^{301}$ such a gift over was taken generally, although the court's attention was not particularly called to the point. ${ }^{302}$

${ }^{290}$ Clifton v. Haig, 4 Des. Eq. 330 (S. C. 1812).

291 Sipra note 27.

${ }^{292}$ Mazyck v. Vanderhorst, 1 Bailey Eq. 48, 52 (S. C. 1828). This case was followed as to land. Adams v. Chaplin, 1 Hill Ch. 265, 268 (S. C. 1830); Edwards v. Edwards, 2 Strob. Eq. 101 (S. C. 1847) ; Hay v. Hay, 3 Rich. Eq. 384 (S. C. 1851) ; cf. Gregg v. Harllee, Dud. Eq. 42 (S. C. 1837). So far as Beresford v. Elliott, 1 Des. Eq. 183 (S. C. 1790) holds the contrary as to land, it must be considered overruled.

${ }^{293}$ DeTreville v. Ellis, 1 Bailey Eq. 40 (S. C. 1827); Stevens v. Patterson,

Bailey Eq. 42 (S. C. 1829); Selman v. Robertson, 46 S. C. 262 (1895).

2041 Rich. Eq. 265 (S. C. 1844).

${ }^{205}$ Spear Eq. 402 (S. C. 1844) (all the contingencies were provided for). 2061 Rich. Eq. 266 (S. C. 1845).

2077 Rich. Eq. 105 (S. C. 1854).

2086 Rich. Eq. 83 (S. C. 1853).

2084 Madd. 11 (1819).

3(1) 10 S. C. 56 (1877). The case was elaborately argued. The court relicd on Vidal v. Verdier, supra note 295, and earlier English cases. The opinion has been properly criticized. See Note (1924) 24 Col. L. REv. 512,515, n. 14.

301105 S. C. 177,89 S. E. 667 (1916).

${ }^{302}$ Chaplin v. Turner, 2 Rich. Eq. 136 (S. C. 1846); Durant v. Nash, 30 S. C. 184,9 S. E. 19 (1888); Marshall v. Marshall, 42 S. C. 436,20 S. E. 298 (1894). 
In Tennessee prior to $1852^{\text {s.3 }}$ the common law rule of indefinite failure of issue was adopted both as to realty and personalty. Little, however, was necessary to cut down the gift over to a failure of issue at the death of the first taker. If the limitation over was to persons "surviving" the first taker, such a result was reached both as to realty and personalty. ${ }^{005}$ And a definite failure was also found upon special context in several cases. ${ }^{300}$

Armstrong v. Douglass ${ }^{30}$ arose under the last clause of the statute of 1852 which provides that there shall be an indefinite failure of issue if the intention "of such limitation be otherwise expressly and plainly declared in the face of the deed or will created." The court found as to the 15th clause in the will under consideration an indefinite failure of issue expressed on the face of the will. This is the only case that the writer has found involving a similar statutory clause in the United States.

More recent cases, however, show a tendency to confine a gift over on death without issue to the lifetime of the testator. In Vaughn v. Cator, ${ }^{308}$ such a gift over of personalty was confined to the testator's lifetime upon the authority of Montagu $v$. Nucella, ${ }^{309}$ where, however, the gifts over exhausted all contingencies. In Meacham v. Graham, 310 the gift over was "without living children." This contingency was cut down to the testator's death on the authority of Vaughn v. Cator and New York cases. Both these cases were approved in Katzenberger $v$. Weaver, ${ }^{312}$ where there was a gift to the first taker's children if he died leaving children.

Meek $v$. Trotter, ${ }^{312}$ where there was a preceding life estate,

303 Tenn. Laws 1851-2, c. 91, p. 113, \& 3.

sos Randolph v. Wendel, 4 Sneed. 646 (Tenn. 1857); Kirk v. Furgerson, 6 Coldw. 479' (Tenn. 1869) (realty); Bowman v. Tucker, 3 Humph. 648 (Tenn. 1842); Chester v. Greer, 5 Humph. 26 (Tenn. 1844) (resity and personalty); Hamner v. Hamner, 3 Head. 398 (Tenn. 1859) (realty and personalty).

${ }^{30}$ Lewis v. Claiborne, 5 Yerg. 369 (Tenn. 1829); Brown v. Hunt, 12 Heisk. 404 (Tenn. 1873); see Booker v. Booker, 5 Humph. 505, 510 (Tenn. 1844).

${ }^{306}$ Williams v. Turner, 10 Yerg. 287 (Tenn. 1837); Bramlet v. Bates, 1 Sneed. 554 (Tenn. 1853) (presented same facts and reached same result as Pells v. Brown, supra note 7) ; Gray v. Bridgeforth, 33 Miss. 312 (1857). 30789 Tenn. 219, 14 S. W. 604 (1890).

30385 Tenn. 302, 2 S. W. 262 (1886).

3091 Russ. 165 (1826).

31098 Tenn. 190, 29 S. W. 12 (1897).

311110 Tenn. 620, 75 S. W. 937 (1903); cf. Stones v. Mraney, 3 Tenn. Ch. 731 (1878) (gift over on death without issue was confined on the special context to death before the first taker reached 35 ).

312133 Tenn. 145, 180 S. W. 176 (1915). 
contained a dictum that the gift over should be confined to the life of the life tenant. The earlier cases were approved and would have been followed had there been no intervening estate.

Anderson v. Lucas ${ }^{313}$ involved a devise of land made in 1843 in which there was a gift if the first taker died without lawful issue. The court followed the earlier Tennessee cases which represented the law at that date and found that an indefinite failure of issue was intended.

\section{VERMONT}

In Chaplin v. Doty, ${ }^{314}$ a gift over upon the first taker's death "without leaving lawful issue" was construed to mean "without having had lawful issue," so that when the legatee survived the testator and begat a child, the gift to the former was held to be absolute. It was assumed that the condition applied after, as well as before, the testator's death. In Dwight v. Eastman, ${ }^{\text {a1 }}$ there was a devise of land to the testator's son and daughter in equal shares. The testator provided that each share should descend to the issue of each of the testator's children, and if no issue to the issue of the other. It was held that the condition operated after the death of the testator. Nothing was said about the exhaustion of all contingencies.

In re Wells's Estate ${ }^{316}$ involved a devise of land to the testator's widow for life, and then to the testator's daughter for life, and then to the heirs of his daughter's body. The will then provided that "should my beloved daughter, Lucia $R$. Ward, die leaving no heirs of her body, or shall $I$, at any future time fail to have heirs of my body, then to a religious society." .The deed was held void for remoteness because the testator intended that it should vest on the death of the daughter without heirs of her body then surviving. But in In Re Thayer's Estate ${ }^{317}$ it was said extra-judicially: "True, the rule must not be overlooked that words of survivorship are presumed to relate to the death of the testator, if fairly capable of such construction."

\section{WISCONSIN}

Wisconsin follows New York where there is no preceding life estate in confining the contingency to the life of the testator. ${ }^{318}$

313140 Tenn. 336, 204 S. W. 989 (1918).

31460 Vt. 712,15 Atl. 362 (1888).

31562 Vt. 398, 20 Atl. 594 (1890).

31669 Vt. 388, 38 Atl. 83 (1897).

31799 Vt. 204, 206, 130 Atl. 683-684; of. Shepard's Heirs v. Shepard's

Estate, 60 Vt. 109, 14 Atl. 536 (1888).

${ }^{318}$ Lovass v. Olson, 92 Wis. 616, 67 N. W. 605 (1896); Patton v. Lud- 
In Chesterfield v. Hoskin, 310 there was a gift to the testator's son for life and, in case of his death without issue and leaving a widow surviving, then to the widow; but if he leave issue, the issue to take. The court held that this meant death after the testator.

In Korm v. Friz, ${ }^{320}$ there was a preceding life estate, and the court took the condition generally upon slight special context. That Korn $v$. Friz went upon the construction of the will is pointed out in Hohnbach v. Hohnbach, ${ }^{321}$ where there was a preceding life estate without special context, and the court confined the contingency to the death of the life tenant.

\section{SUMMARY}

The unfortunate rule fettering a gift over on death without issue to the period of distribution exists in Alabama, Connecticut, Indiana, Iowa, Maryland, Pennsylvania, Rhode Island, Tennessee and Wisconsin. It probably exists also in New York and South Carolina. It appears in part in Kentucky and New Jersey. Georgia, Illinois and Vermont may be classified as doubtful states.

The statute presuming a definite failure of issue at the death of the first taker has hardly ever been discussed in these authorities. Even if the condition is to be confined to the death of the testator, or of a prior life tenant, the question might well still be open whether $A$ 's death without issue is intended to be upon $A$ 's indefinite failure of issue before the testator or the life tenant.

Perhaps the most sensible suggestion is made in Buchanan $v$. Buchanan, ${ }^{322}$ that the statute itself precludes reference to any other period than the death of the first taker. The effect of this construction would be to do away entirely, in those states having such an act, with the anomalous body of authority just considered at length. ${ }^{323}$

ington, 103 Wis. 629, 79 N. W. 1073 (1899); Owens' Will, 164 Wis. 260, 159 N. W. 906 (1916); Will of O'Brien, 173 Wis. 41,180 N. W. 141 (1920). 318133 Wis. 268,113 N. W. 647 (1907).

320128 Wis. 428,107 N. W. 659 (1906).

321151 Wis. 487,139 N. W. 731 (1913).

322 Supra note 239.

${ }^{323}$ Cf. Siegwarth's Estate, 33 Pa. Super. Ct. 622 (1907) with Buchanan v. Buchanan, supra note 239. The cases seem to conflict. See Updegraft, op. cit. supra note 86 , at $255-256$.

In Doud v. Scally, 184 N. W. 340 (Iowa 1921), after a gift to the testator's wife for life there was a remainder to his children: but should any of his children die without issue before his wife, then to the survivors of them on her death: and should any die without leaving issue, the issue on his wife's death were to take their parent's share. One of the testator's children died after his death and before his wife, leaving two children who died unmarried before the life tenant. It was held that the testator's child had died with issue and the heir of that child's deceased issue tool: under the gift to them in the will. 